\title{
Evidence for two distinct KiSS genes in non-placental vertebrates that encode kisspeptins with different gonadotropin-releasing activities in fish and mammals
}

\author{
Alicia Felip ${ }^{1}$, Silvia Zanuy ${ }^{1}$, Rafael Pineda ${ }^{2}$, Leonor Pinilla ${ }^{2}$, Manuel Carrillo ${ }^{1}$, \\ Manuel Tena-Sempere ${ }^{2}$, Ana Gómez ${ }^{1 *}$
}

${ }^{1}$ Consejo Superior de Investigaciones Científicas (CSIC), Instituto de Acuicultura de Torre de la Sal (IATS), Ribera de Cabanes 12595 Castellón, Spain.

${ }^{2}$ Department of Cell Biology, Physiology, and Immunology, University of Córdoba; and CIBER Fisiopatología de la Obesidad y Nutrición, 14004 Córdoba, Spain.

*Corresponding author: Ana Gómez. Instituto de Acuicultura de Torre la Sal (CSIC). Ribera de Cabanes s/n. 12595 Torre la Sal. Castellón. Spain. Phone: +34 964319500. Fax: +34 964 319509. e-mail: ana@iats.csic.es 
Key words: KiSS-1, KiSS-2, vertebrate evolution, LH, FSH, Dicentrarchus labrax, Rattus norvegicus

\section{Summary.}

Kisspeptins, the products of KiSS-1 gene, have recently emerged as fundamental regulators of reproductive function in different mammalian and, presumably, nonmammalian species. To date, a single form of KiSS- 1 has been described in mammals, and recently, in several fish species and Xenopus. We report herein the cloning and characterization of two distinct KiSS-like genes, namely, KiSS-1 and KiSS-2, in the teleost sea bass. While KiSS-1 encodes a peptide identical to rodent kisspeptin-10, the predicted KiSS-2 decapeptide diverges at 4 amino acids (FNFNPFGLRF). Genome database searches showed that both genes are present in non-placental vertebrate genomes. Indeed, phylogenetic and genome mapping analyses suggest that KiSS-1 and KiSS-2 are paralogous genes that originated by duplication of an ancestral gene, although KiSS-2 is lost in placental mammals. KiSS-1 and KiSS-2 mRNAs are present in brain and gonads of sea bass, medaka and zebrafish. Comparative functional studies demonstrated that KiSS2 decapeptide was significantly more potent than KiSS-1 peptide in inducing LH and FSH secretion in sea bass. In contrast, KiSS-2 decapeptide only weakly elicited LH secretion in rats, whereas KiSS-1 peptide was maximally effective. Our data are the first to provide conclusive evidence for the existence of a second KiSS gene, KiSS-2, in nonplacental vertebrates, whose product is likely to play a dominant stimulatory role in the regulation of the gonadotropic axis at least in teleosts. 


\section{Introduction}

Identification and characterization of the physiological roles of the so-called KiSS-1 system is a major breakthrough in modern Neuroendocrinology that has revolutionized the area of vertebrate reproduction (de Roux et al., 2003; Seminara et al., 2003; Matsui et al., 2004; Kaiser and Kuohung, 2005; Seminara, 2005; Seminara and Kaiser, 2005; Gottsch et al., 2006; Roa and Tena-Sempere, 2007; Roa et al., 2008). Thus, in the last five years, kisspeptins, a family of structurally related peptides encoded by the KiSS-1 gene with ability to activate the G-protein coupled receptor 54 (GPR54), have been proven to play a major role in the regulation of the gonadotropic axis, with essential functions in the timing of puberty onset and the control of gonadotropin secretion in mammals, including rodents (Seminara et al., 2003; Navarro et al., 2004b), livestocks (Smith, 2008), primates (Shahab et al., 2005) and humans (Seminara et al., 2003; Dhillo et al., 2005). In addition, recent data have established an important role of kisspeptins in other relevant reproductive phenomena, such as the metabolic control of fertility (Fernández-Fernández et al., 2006; Luque et al., 2007; Castellano et al., 2008), the regulation of reproductive capacity by environmental cues (Roa et al., 2008) and, tentatively, the control of placental formation and pregnancy (Horikoshi et al., 2003). Moreover, kisspeptins have been involved, among other functions, in the regulation of cardiovascular system (Mead et al., 2007), adipocyte biology (Brown et al., 2008) and pancreatic secretion (Roa et al., 2008; for review).

The awakening of the gonadotropic axis at puberty is a crucial process in order to attain full reproductive capacity; a phenomenon that occurs in mammals (Colledge, 2004; Hofmann, 2006; Roa and Tena-Sempere, 2007; Roa et al., 2008) and also in nonmammalian species, such as fish (Okuzawa, 2002; Weltzien et al., 2004). Therefore, to gain better understanding of the neuroendocrine mechanisms and genetic basis for the control of sexual maturation remains as a fundamental challenge in animal physiology. In humans and mice, mutations in GPR54 have been associated to pubertal delay, supporting the idea that kisspeptin/GPR54 signaling plays a key regulatory role in puberty onset (de Roux et al., 2003; Seminara et al., 2003). Moreover, administration of exogenous kisspeptins has been shown to potently activate the gonadotropic axis acting primarily at the level of hypothalamic gonadotropin-releasing hormone $(\mathrm{GnRH})$ neurons (Murphy, 2005; Roa and Tena-Sempere, 2007). Indeed, several studies have documented that kisspeptins elicit GnRH secretion, which in turn leads to gonadotropin release and increased circulating levels of testosterone in rodents (Matsui et al., 2004; Thompson et al., 2004; Messager et al., 2005; Navarro et al., 2005a;b; Castellano et al., 2006b) and primates (Shahab et al., 2005; Plant et al., 2006), including humans (Dhillo et al., 2005). Furthermore, administration of kisspeptins has been reported to advance the onset of puberty in rats (Navarro et al., 2004b) and to stimulate ovulation in female rats (Matsui et al., 2004; Kinoshita et al., 2005) and pony mares (Briant et al., 2006). In addition, in mammals, expression of KiSS-1 and GPR 54 genes has been demonstrated in discrete hypothalamic areas that play key roles in the negative and positive feedback control of gonadotropin secretion by sex steroids and in the metabolic regulation of fertility (Seminara, 2005; Dungan et al., 2006; Roa et al., 2008). Indeed, kisspeptin immunoreactivity has been reported in neurons expressing both estrogen and androgen receptors (Kinoshita et al., 2005; Smith, 2008), and it is well characterized that 
hypothalamic expression of the KiSS-1 gene is under the control of sex steroids in rodents (Navarro et al., 2004a; Smith et al., 2005; Smith, 2008), sheep (Smith et al., 2006b; Smith, 2008) and primates (Shibata et al., 2007). Likewise, regulation of hypothalamic KiSS-1 mRNA levels by key metabolic signals, such as leptin, has been demonstrated in rats (Castellano et al., 2006c) and mice (Smith et al., 2006a).

In contrast to the rapid progress of our knowledge in mammals described above, little information regarding the structure, function and regulation of the KiSS-1 system exists in non-mammalian species (Roa and Tena-Sempere, 2007; Roa et al., 2008). While the GPR54 gene has been cloned and characterized in several fish species (Parhar et al., 2004; Mohamed et al., 2007; Nocillado et al., 2007; Biran et al., 2008; Filby et al., 2008; Mechaly et al., 2008; van Aerle et al., 2008) and Xenopus (Moon et al., 2008), to date molecular cloning of KiSS-1 is restricted to zebrafish (Danio rerio) (Biran et al., 2008; van Aerle et al., 2008) and medaka (Oryzias latipes) (Kanda et al., 2008). Yet, bioinformatic approaches have been recently used to identify the KiSS-1 gene in different mammals (Biran et al., 2008; Moon et al., 2008; van Aerle et al., 2008), Xenopus (Biran et al., 2008; Moon et al., 2008) and non-mammalian species, including the sea lamprey and teleost fish (Biran et al., 2008; Moon et al., 2008; van Aerle et al., 2008).

We report herein the cloning of the full-length cDNAs encoding two distinct KiSS-like genes, named KiSS-1 and KiSS-2, in the sea bass (Dicentrachus labrax L.), an aquacultured marine teleost. Co-existence of both genes was found in the genome databases of different vertebrate non-mammalian species such as the sea lamprey, several fish species, amphibians and squamates, as well as in a non-placental mammalian vertebrate, the platypus. In clear contrast, placental vertebrate genomes contained only the KiSS-1 gene. Expression analyses suggest the presence of KiSS-1 and KiSS-2 products in the brain and the gonads of teleosts, whereas functional analyses demonstrate that the predicted KiSS-2 peptide is more potent than KiSS-1 in inducing gonadotropin secretion in the sea bass, but weakly active in rats -as representative mammalian species-.

\section{Material and Methods}

\subsection{Animals and tissue sample collection}

Sea bass (sbs) and medaka (md) (Carbio strain) were obtained from stocks at IATS, whereas zebrafish (zf) were obtained from a local pet shop. Brain and gonads were collected from male and female prepubertal and adult sea bass $(n=1-4$ for each sex and developmental stage) in January, February, March and April. Besides, different somatic tissues were also collected from the samples in January. Finally, different tissues of adult male and female medaka and zebrafish $(n=4-5$ for each sex) were collected. All samples were frozen on dry ice and stored at $-80^{\circ} \mathrm{C}$.

For in vivo testing of kisspeptins, adult Wistar male rats, bred in the vivarium of the University of Córdoba, were used. The animals were maintained under constant conditions of light (14 h of light, from 07:00) and temperature $\left(22^{\circ} \mathrm{C}\right)$, and were housed in individual cages with free access to pelleted food and tap water. Experimental procedures were approved by the corresponding local Ethical Committees for animal experimentation. All the in vivo experiments were conducted in accordance with the European Union normative for use of experimental animals. 


\subsection{Molecular cloning of two KiSS-like genes in the sea bass}

To amplify fragments of sea bass KiSS-1, degenerate PCR primers were designed based on 12 conserved amino acids from the medaka, zebrafish, Fugu and Tetraodon putative KiSS-1 that included the kisspeptin-10 sequence $\left((\mathrm{Y} / \mathrm{F}) \mathrm{NLN}(\mathrm{S} / \mathrm{P}) \mathrm{FGLR}(\mathrm{Y} / \mathrm{F}) \mathrm{GK}-\mathrm{NH}_{2}\right)$. PCR amplifications were carried out from 4 sea bass genomic DNA libraries constructed with the Universal GenomeWalker Kit (Clontech Laboratories Inc.). Primary PCR amplifications were performed by using a primer (AP1) complementary to the adaptor sequence provided with the kit and degenerate KiSS-1 PCR primers (first PCR sense, K1: 5' -

TWYAAYCTNAAYYCITTYGGYCYCCG-3'; antisense, K3: 5'TTKCCRWARCGGAGRCCRAAIGRRTT-3'). Secondary and nested PCRs were performed by using a primer (AP2) complementary to the adaptor sequence provided with the kit and degenerate and nested KiSS-1 PCR primers (second PCR sense, K2: 5' AACYCITTYGGYCTCCGYTWYGGNAA-3'; antisense K4: 5'CGGAGRCCRAANGRRTTIAGRTTRWA-3'). PCR conditions were as follow: denaturation at $94^{\circ} \mathrm{C}$ for $30 \mathrm{sec}$, followed by 7 cycles at $94^{\circ} \mathrm{C}$ for $20 \mathrm{sec}$ and $76^{\circ} \mathrm{C}$ for 3 min and 32 cycles at $94^{\circ} \mathrm{C}$ for $20 \mathrm{sec}$ and $68^{\circ} \mathrm{C}$ for $3 \mathrm{~min}$, and $68^{\circ} \mathrm{C}$ for $7 \mathrm{~min}$ after the final cycle. For the secondary PCR, the primary PCR product was diluted $1 / 50$ and PCR conditions were as follow: $94^{\circ} \mathrm{C}$ for $30 \mathrm{sec}$, followed by 7 cycles at $94^{\circ} \mathrm{C}$ for $20 \mathrm{sec}$ and $76^{\circ} \mathrm{C}$ for $3 \mathrm{~min}$ and 32 cycles at $94^{\circ} \mathrm{C}$ for $20 \mathrm{sec}$ and $70^{\circ} \mathrm{C}$ for $3 \mathrm{~min}$, and a final step of $70^{\circ} \mathrm{C}$ for $7 \mathrm{~min}$. PCR products were cloned into the pGEM-T Easy Vector (Promega) and further sequenced. The full-length cDNAs of KiSS-1 and KiSS-2 were obtained from a sea bass brain cDNA library constructed in the UNI ZAP-XR vector. Initially, PCR reactions using gene-specific primers in combination with primers annealing in the UNI Zap-XR vector were performed to obtain the cDNA ends. Then, specific primers corresponding to the 5' and 3' ends of KiSS-1 (sense kiss1-15 5'GATGCCACGACTCATTGTCGCTC-3'; antisense kiss1-16 5'-

AATCTTTAACCAACATTTTTATTGAG-3') and KiSS-2 (sense kiss2-16 5'GGCACGAGGAGACACACACAC-3'; antisense kiss2-17 5'-TAA

CCATACAGTGCTTTTATTGTG-3') cDNAs were used to amplify the full-length on a sea bass brain cDNA by using a proofreading DNA polymerase ( $P f u$ DNA polymerase; Stratagene). To examine the presence of introns in the coding regions of both genes the primer sets kiss1-13 (sense 5'CTCATTGTCGCTCTGATGATAGC-3') and kiss1-7 (antisense 5'-GGGCTTTGAGTA TTACCTGATCTGA-3') were used for KiSS-1, whereas kiss2-16 and kiss2-17 were used for KiSS-2 in PCR amplifications on sea bass gDNA.

\subsection{Sequence database searches, alignments, phylogenetic and genome mapping analyses}

All TBLASTN searches against the genome assemblies of different vertebrate species and retrieval of data for synteny analysis were performed at Ensembl (Ensembl Genome Browser, http://www.ensembl.org). The sequence of the sea bass KiSS-1 (YNLNSFGLRY) and KiSS-2 (FNFNPFGLRF) kisspeptin-10 motifs were used to query the putative gene sequences in other vertebrates. Multiple amino acid sequence alignments were generated with ClustalX (1.83) (Thompson et al., 1997). Protein 
phylogenetic analysis was conducted with MEGA4 using the Neighbor-Joining method (Tamura et al., 2007).

\subsection{RNA isolation and RT-PCR analysis}

Total RNA was extracted from fish tissues with TRI-REAGENT (Sigma) according to the manufactures' instructions. Reverse transcription was performed on $2 \mu \mathrm{g}$ of total RNA with the presence of $100 \mathrm{ng}$ of random hexamers and using SuperScript II Reverse Transcriptase (Invitrogen). For expression analysis, two sets of gene-specific primers located in two different exons were designed for sea bass, medaka and zebrafish KiSS-1 and KiSS-2 genes (Table 1). RT-PCR analyses were performed using a touchdown PCR approach. It comprised a $10-15^{\circ} \mathrm{C}$ span of annealing temperatures, as follows: a denaturing step at $94^{\circ} \mathrm{C}$ for 2 min followed by $30\left(15^{\circ} \mathrm{C}\right.$ span $)$ or $20\left(10^{\circ} \mathrm{C}\right.$ span $)$ cycles of $94^{\circ} \mathrm{C}$ for $30 \mathrm{~s}$, the highest annealing temperature for $30 \mathrm{~s}$, and $72^{\circ} \mathrm{C}$ for $45 \mathrm{~s}$. The annealing temperature was decreased $0.5^{\circ} \mathrm{C}$ per cycle and followed by 10 or 20 cycles of $94^{\circ} \mathrm{C}$ for $30 \mathrm{~s}$, the lowest annealing temperature for $30 \mathrm{~s}$, and $72^{\circ} \mathrm{C}$ for $45 \mathrm{~s}$ with a final extension step at $72^{\circ} \mathrm{C}$ for $5 \mathrm{~min}$. The elongation factor- $1 \alpha(e f 1 \alpha)$ gene was used in the three fish species as reference gene using specific primers (Table 1). Cycling conditions consisted of $94^{\circ} \mathrm{C}$ for $2 \mathrm{~min}$ followed by 25 cycles at $94^{\circ} \mathrm{C}$ for $30 \mathrm{~s}, 58^{\circ} \mathrm{C}$ for $45 \mathrm{~s}$, and $72^{\circ} \mathrm{C}$ for $45 \mathrm{~s}$ with a final extension step at $72^{\circ} \mathrm{C}$ for $1 \mathrm{~min}$.

\subsection{Peptides}

According to the deduced amino acid sequences of the kisspeptin-10 region in the sea bass proteins, sbsKiSS-1 ( $\left.\mathrm{NH}_{2}-\mathrm{YNLNSFGLRY-CONH} 2\right)$ and sbsKiSS-2 $\left(\mathrm{NH}_{2}-\right.$ FNFNPFGLRF-CONH2) amidated peptides were synthesized by Thermo Fisher Scientific (Ulm, Germany).

\subsection{Administration of kisspeptins to sea bass}

In a first experiment, the ability of sbsKiSS-1 and sbsKiSS-2 peptides to elicit luteinizing hormone (LH) and follicle-stimulating hormone (FSH) secretion was assessed in prepubertal fish (1-year-old sea bass; $100 \mathrm{~g}$ in body weight, BW) by intramuscular (i.m.) administration in vivo at a dose of $250 \mathrm{ng}$ of each peptide per gram of BW. The dose of kisspeptin was chosen on the basis of previous reported effects of KiSS-1 peptide administration on gonadotropin secretion in mammals (Navarro et al., 2005a;b). Groups of animals ( $\mathrm{n}=5-10)$ were sequentially sampled before $(0)$ and at 15-, 30-, 60-, 120-, 240-min after i.m. injection. In a second experiment, we investigated the stimulatory effect of both peptides on LH secretion in adult male sea bass (2-year-old; $200 \mathrm{~g} \mathrm{BW}$; $250 \mathrm{ng}$ of each peptide per gram of BW). Groups of animals $(n=5-10)$ were sequentially sampled before (0) and at 60-, 120-, 180- and 240-min after i.m. injection.

In both experiments animals injected phosphate buffered saline served as controls. Blood samples were collected by caudal puncture, and plasma was separated by centrifugation at $2.500 \mathrm{xg}$ for $30 \mathrm{~min}$ at $4^{\circ} \mathrm{C}$ and stored at $-20^{\circ} \mathrm{C}$.

\subsection{Administration of kisspeptins to rats}

In a first experiment, we tested the ability of sbsKiSS-1 (identical to rat $/$ mouse kisspeptin-10) and sbsKiSS-2 peptides to elicit LH and FSH secretion in adult rats ( $\mathrm{n}=$ 
10) after intracerebroventricular (i.c.v.) administration, following previously validated procedures (Navarro et al., 2004a; 2005a;b). A dose of $100 \mathrm{pmol} / \mathrm{rat}$ was selected on the basis of previous references (Navarro et al., 2005a;b), in order to achieve sub-maximal stimulation. To allow delivery of kisspeptins into the lateral cerebral ventricle, the animals were implanted, under ether anesthesia, with i.c.v. cannulae lowered to a depth of $4 \mathrm{~mm}$ beneath the surface of the skull; the insert point was $1 \mathrm{~mm}$ posterior and $1.2 \mathrm{~mm}$ lateral to bregma, as described elsewhere (Navarro et al., 2004a; 2005a;b). Blood samples $(300 \mu \mathrm{L})$ were obtained by jugular venipuncture under light ether anesthesia, before $(0)$ and at 15-, 30-, 60- and 120-min after kisspeptin injections. Animals injected with physiological saline $(0.9 \% \mathrm{NaCl})$ served as controls.

In a second experiment, we investigated the effects of sbsKiSS-1 and sbsKiSS-2 peptides on LH and FSH secretion in adult rats $(\mathrm{n}=10)$ after intraperitoneal (i.p.) administration, following previously validated procedures (Navarro et al., 2005a;b). A dose of $15 \mu \mathrm{g} / \mathrm{rat}$ was selected for i.p. injection on the basis of previous reports (Navarro et al., 2005a,b). Blood samples $(300 \mu \mathrm{L})$ were obtained by jugular venipuncture under light ether anesthesia, before (0) and at 15-, 30-, 60- and 120-min after kisspeptin injections. Animals injected with physiological saline $(0.9 \% \mathrm{NaCl})$ served as controls. In both experiments, sera were obtained by centrifugation of blood samples at $2.500 \mathrm{x} g$ for $30 \mathrm{~min}$ at $4^{\circ} \mathrm{C}$, and stored at $-20^{\circ} \mathrm{C}$ until used for hormone measurements.

\subsection{Hormonal analyses}

For hormonal tests in fish, plasma LH levels were determined using a validated enzyme-linked immunoassay for sea bass (Mateos et al., 2006). The detection limit was $0.65 \mathrm{pg} / \mathrm{ml}$ (Bi/Bo 80\%), with intra- and interassay coefficient of variation of $11.7 \%(\mathrm{n}=$ $8)$ and $11 \%(n=10)$, respectively. Levels of bioactive sea bass FSH in plasma were estimated using a HEK293 stable clone constitutively expressing the sea bass FSHR (Rocha et al., 2007) and the firefly luciferase gene under the control of a cAMP responsive promoter (pCRE). Sea bass FSHR activation was measured by changes in luciferase activity (relative light units, RLU). The assay was performed as described (Moles et al., 2008), but scaling to 96 well plates. Plasma samples were diluted 1/25, and measured in triplicate at least in two independent analysis. After $6 \mathrm{~h}$ incubation luciferase activity was quantified directly on the plates using the Steady-Glo Luciferase Assay System (Promega) and the ULTRA Evolution (TECAN) detection platform. Intra- and interassay coefficients of variation were respectively $6.9 \%$ and $9.5 \%$. The detection limit was $131.6 \%$ over unstimulated cells.

In rat experiments, serum LH and FSH levels were determined in a volume of 25$50 \mu \mathrm{l}$ using a double-antibody method and radioimmunoassay kits supplied by the NIH (Dr. AF Parlow, NIDDK National Hormone and Peptide Program; Torrance, CA, USA). Rat LH-I-10 and FSH-I-9 were labeled with ${ }^{125}$ I using Iodo-gen ${ }^{\circledR}$ tubes, following the instructions of the manufacturer (Pierce, Rockford, IL, USA). Hormone concentrations were expressed using reference preparations LH-RP-3 and FSH-RP-2 as standards. Intraassay coefficients of variation were, respectively, $<10 \%$ for $\mathrm{LH}$, and $<8 \%$ for FSH. The sensitivity of the assay was $5 \mathrm{pg} /$ tube for LH and $20 \mathrm{pg} /$ tube for FSH. For each hormone, all samples were measured in the same assay. Accuracy of hormone determinations was confirmed by assessment of rat serum samples of known hormone concentrations used as external controls. 


\subsection{Statistics}

Hormonal data were analyzed for statistically significant differences using ANOVA test followed by Student-Newman-Keuls multiple range test (SigmaStat 3.0). Data are presented as mean \pm S.E.M. Differences were accepted as significant when $P<$ 0.05 (Sokal and Rohlf, 1981).

\section{Results}

\subsection{Cloning of sea bass KiSS-1 and KiSS-2}

Using degenerate primers and the Universal GenomeWalker Kit, we obtained two PCR fragments of $110 \mathrm{bp}$ and $190 \mathrm{bp}$ that corresponded to genomic sequence 5' upstream from kisspeptin-10 conserved motif of the sea bass KiSS-1 and KiSS-2 genes, respectively, and a $200 \mathrm{bp}$ fragment containing KiSS-2 sequence 3' downstream from kisspeptin-10. The full cDNA sequences of both genes were obtained from a sea bass brain cDNA by using specific primers. The complete sea bass KiSS-1 cDNA has a length of $561 \mathrm{bp}$. It consists of an open reading frame (ORF) of $309 \mathrm{bp}$ that codes for a 103 amino acid peptide, flanked by 5'and 3'UTRs of $116 \mathrm{bp}$ and $133 \mathrm{bp}$, respectively. On the other hand, the sea bass KiSS-2 cDNA consists of 744 bp with an ORF of 366 bp that codes for a 122 amino acid peptide, flanked by 5'and 3'UTRs of 26 bp and $349 \mathrm{bp}$, respectively (Fig. 1A). The first 20 amino acids in KiSS-1 and the first 15 amino acids in KiSS-2 were predicted to constitute the putative signal peptide. The amino acid sequences of sea bass KiSS- 1 and KiSS- 2 are $<20 \%$ identical, except for the putative kisspeptin-10 (sbsKiSS-1: YNLNSFGLRY; sbsKiSS-2: FNFNPFGLRF), where they share 6 out of 10 amino acids (Fig. 1B). Each of these genes contains two coding exons and one intron located in a similar position of the coding region. The KiSS-1 and KiSS-2 introns are 1895 and $2200 \mathrm{bp}$ in length, respectively.

\subsection{Identification, phylogenetic and synteny analyses of KiSS-1 and KiSS-2 genes in vertebrates}

Searches in different available genome databases evidenced that KiSS-1 and KiSS2 are also present in other vertebrate species such as the sea lamprey, zebrafish, medaka, Xenopus, and the non-placental mammal platypus, while some of the screened genomes showed only one of these two genes. KiSS-2 was not found in the human, mouse, rat and opossum genomes, which contain the KiSS-1 gene. On the contrary, KiSS-2, but not KiSS1, was found in the stickleback, Fugu, Tetraodon and lizard. Neither KiSS-1 nor KiSS-2 were found in the chicken genome (Fig. 1B). Comparisons of these vertebrate KiSS genes with those of sea bass revealed that their sequences are highly divergent, except for the kisspeptin-10 coding region that is well conserved, both among species and between the KiSS-1 and KiSS-2 representatives. However, the deduced proteins have a similar structure with a signal sequence in the amino terminus and the kisspeptin-10 motif located near the carboxy terminus.

To study the evolutionary relationship of the KiSS genes in vertebrates, phylogenetic and synteny analyses were performed. In the phylogenetic analysis, the topology of the resulting unrooted tree showed two main groups, KiSS-1 and KiSS-2, 
which appear as separated branches from the base of the vertebrate radiation (Fig. 2A). Mapping of KiSS-1 and KiSS-2 in the available genomes revealed that these two genes are located in different chromosomes in all the species where both genes co-exist. Besides, comparison of the chromosomal regions containing KiSS-1 or KiSS-2 in different species uncovered a conserved synteny within each gene (Fig. 2B-C). The gene organization around human KiSS-1 (SOX13, ETNK2, REN, GOLT1A, PLEKHA6, $P I K 3 C 2 B$ and $P P P 1 R 15 B)$ is nearly identical to that found in mouse, rat, opossum and chicken (Fig. 2B). A less conserved synteny was found with fish species. Although medaka and stickleback show a highly syntenic region between them. Thus, genomic organization of these putative ortologs that clustered with KiSS-1 revealed the absence of the KiSS- 1 gene in chicken and stickleback, confirming our failure in the database searches. On the other hand, in all the fish species analyzed KiSS-2 was followed by the same genes in one side ( $L D H B, S L C 25 A 3, T M P O$ and STRAP), whereas GYS2, C12orf39 and $G O L T 1 B$ mapped on the other side except for medaka where some variation was found. In mammals, GOLT1B, C12orf39, GYS2 and $L D H B$ show the same gene order as in fish, although KiSS-2 was not identified between GYS2 and $L D H B$ as it was found in teleosts (Fig. 2C). Furthermore, some paralogous genes were identified to be located surrounding KiSS-1 and KiSS-2 genes. We consider that this might constitute an ancestral paralogon, where the corresponding KiSS gene would be included. This is the case of the pairs GOLT1A/GOLT1B, PLEKHA5/PLEKHA6, PIK3C2B/PIK3CG or ETNK1/ETNK2. Besides, for each pair only one co-orthologue could be found in invertebrate chordates (Ciona) suggesting that these genes resulted from a duplication event that occurred at least after the divergence of Urochordata and Vertebrata.

\subsection{Tissue distribution of KiSS-1 and KiSS-2}

Results showed that $s b s K i S S-1$ and $s b s K i S S-2$ were predominantly expressed in brain and gonadal tissues (testis and ovary). In addition, sbsKiSS- 1 was clearly expressed in the heart in juvenile males (Fig. 3A-upper left panel). In medaka, mdKiSS-1 was expressed in brain and testis, with lower levels of expression in eye and skin of adult males and in the ovary, gill and eye in adult females (Fig. 4-upper panel). The mdKiSS-2 was highly expressed in brain and a weaker expression was observed in testis and ovary. The presence of $m d K i S S-2$ was also detected in intestine, heart, eye and skin of adult males and in the gills of adult females. A faint expression was found in spleen, adipose tissue, liver and intestine of adult females. In zebrafish, zfKiSS- 1 was highly expressed in the brain of males and females with moderate levels of expression in gonadal tissues. Besides, $z f K i S S-1$ mRNA was found in a wide range of tissues, although with different levels of expression (Fig. 4-low panel). On the other hand, tissue distribution of zfKiSS-2 was limited to brain and ovary with low levels of expression in the testis (Fig. 4-lower panel).

\subsection{Temporal mRNA expression of KiSS-1 and KiSS-2 during the reproductive season of sea bass}

Considering the notable levels of expression of sbsKiSS-1 and sbsKiSS-2 in the brain, testis and ovary of adult and juvenile sea bass from both sexes at the beginning of the reproductive season (January), sample collection was monthly extended throughout the whole reproductive season (February-April). Overall, the levels of expression of 
sbsKiSS-1 and sbsKiSS-2 were higher in the brain than in the testis or ovary, regardless of the developmental stage or sex during the reproductive period. Particularly, in juvenile females sbsKiSS-1 expression in the brain was weaker than that of sbsKiSS-2, which showed robust expression levels during the whole reproductive period (Fig. 3B-lower left panel). In gonadal tissues, while the level of expression of sbsKiSS-1 was weak in the testis and ovary of adult males and females from January to April, notable expression levels were observed in the testis of juvenile males for the same period, whereas in juvenile females, expression of $s b s K i S S-1$ in the ovary was restricted to January. We also detected moderate levels of expression of $s b s K i S S-2$ in the gonads of adult males and females. In juvenile fish, modest expression levels of $s b s K i S S-2$ were observed in the testis, whereas in the ovary high levels of expression were detected in January, which declined in February, and became undetectable for that point onwards (Fig. 3B-upper right panel).

\subsection{Effects of administration of kisspeptins on LH and FSH secretion in sea bass}

Functional analyses were conducted to test the gonadotropin-releasing capacity of sbsKiSS-1 and sbsKiSS-2 peptides in their homologous species. Systemic (i.m.) administration of both kisspeptins to prepubertal sea bass evoked significant elevations in circulating LH levels at 120 min after injection (Fig. 5A). However, while sbsKiSS-2 elicited a $\sim 4$-fold increase in mean LH concentrations over the corresponding preinjection levels, sbsKiSS-1 peptide induced only a $\sim 2$-fold increase. In the same vein, maximal FSH secretory response of $\sim 2$-fold increase was observed at $60 \mathrm{~min}$ after sbsKiSS-2 peptide injection, while sbsKiSS-1 peptide was able to induce only a moderate not significant increase of FSH secretion at $120 \mathrm{~min}$ after injection (Fig. 5B). In addition, testing of the ability of both peptides to elicit LH secretion in vivo in 2-yr-old adult male sea bass revealed that only sbsKiSS-2 peptide elicited an increase of LH levels at $120 \mathrm{~min}$ after injection, which due to sample variability fell shortly below statistical significance (Fig. 5C). In contrast, at the dose tested, sbsKiSS-1 peptide was clearly ineffective in inducing LH secretion in adult male sea bass.

\subsection{Effects of administration of kisspeptins on LH and FSH secretion in rats}

Functional analyses also included testing of the effects of sea bass kisspeptins in a heterologous mammalian species, the rat. Considering that sbsKiSS-1 is identical to rat $\mathrm{Kp}-10$, and in order to avoid supra-physiological stimulation, sub-maximal, equimolar doses of kisspeptins were selected for central (i.c.v.; 100 pmol/rat) and systemic (i.p.; 15 $\mu \mathrm{g} / \mathrm{rat}$ ) administration, in keeping with previous studies on the gonadotropin releasing effects of rat Kp-10. In adult male rats, both i.c.v. and i.p. administration of sbsKiSS-1 elicited a robust increase in plasma LH levels, with maximal stimulation at 15 min after injection, and persistent elevation of plasma LH levels at 30 and 60 min after i.c.v. administration (Fig. 6A), and at 30 min after i.p. administration (Fig. 6B) of the peptide. In contrast, injection of sbsKiSS-2 induced a very modest increase in plasma LH levels only at 15 min after i.c.v. administration (Fig. 6A), whereas no stimulatory LH response to sbsKiSS-2 peptide was observed after i.p. injection of the peptide (Fig. 6B). On the other hand, plasma FSH concentrations were moderately elevated in adult male rats at 30 and 60 min after i.c.v. administration of sbsKiSS-1 peptide, while sbsKiSS-2 was not able 
to evoke any FSH secretory response after central injection (Fig. 6C). Finally, systemic (i.p.) administration of neither sbsKiSS-1 nor sbsKiSS-2 peptides induced further increases in serum FSH levels, at any time-point studied (Fig. 6D).

\section{Discussion}

This is the first description of the co-existence of two kisspeptin coding genes, namely KiSS-1 and KiSS-2, within the same species, the teleost fish sea bass. Importantly, this phenomenon appears to be generalized in non-placental vertebrates. In addition, the functional tests reported herein evidence that, despite full conservation of KiSS-1 decapeptide from fish to mammals, the KiSS-2 peptide is likely provided with a much potent gonadotropin releasing activity in sea bass, thus suggesting a dominant role of this non-mammalian kisspeptin in the control of the gonadotropic axis, at least in teleosts.

To date, all the KiSS-like sequences annotated have been considered as KiSS-1, as existence of only one gene was predicted in each vertebrate genome characterized so far. However, some of the non-mammalian KiSS-1 sequences annotated correspond to the 'novel' KiSS-2 gene reported here. Thus, while sequences initially described in medaka, zebrafish and sea lamprey (Biran et al., 2008; Kanda et al., 2008; Moon et al., 2008; van Aerle et al., 2008) do correspond to KiSS-1, the KiSS gene identified in the pufferfishes Fugu and Tetraodon, as well as in the amphibian Xenopus laevis (Moon et al., 2008; van Aerle et al., 2008), was actually KiSS-2. Most recently, the mammalian form, KiSS-1, was independently described in Xenopus (Biran et al., 2008), but without recognition of the presence of both genes in this species. Departing from the molecular cloning of KiSS-1 and KiSS-2 in sea bass, our study provides conclusive evidence for the co-existence of both KiSS genes in the genome of several vertebrate species, as revealed by searching of different available genome databases. Based on our phylogenetic and synteny analyses, we propose that KiSS-1 and KiSS-2 are present since very early in vertebrate evolution, as the co-existence of both genes in a single genome could be detected both in Agnatha (sea lamprey) and Gnathostoma (teleosts, amphibian, monotrema).

Of particular interest, gene mapping analysis revealed that, when identified in the same species, both KiSS- 1 and KiSS-2 genes were located in different chromosomes, but each one in genomic regions with conserved synteny across vertebrate species. Some of the genes identified in our study in the syntenic region of KiSS-1 are in agreement with the findings recently described for human, mouse and zebrafish for these loci (van Aerle et al. 2008). In addition, the syntenic regions that we describe among human chromosome 1 (Chr1), mouse Chr1, chicken Chr26 and medaka Chr5 in the case of KiSS-1, and human Chr12, mouse Chr6, chicken Chr1 and medaka Chr23 for KiSS-2, are in accordance with syntenic regions already described for the genomes of these species (Nakatani et al., 2007).

Marsupial (opossum) and placental (human, mouse, rat) mammals harbor the KiSS-1 gene (Biran et al., 2008; Moon et al., 2008; van Aerle et al., 2008), but KiSS-2 was not found in the available genomic data of these organisms. However, we found genomic regions in these species syntenic to those where KiSS-2 is located in teleosts. Thus, we suggest that a gene loss event subsequently occurred for KiSS-2 affecting all the live-bearing mammalian lineages, likely as a result of a specific speciation event. 
Similarly, we could not find KiSS-1 in some fish species as Fugu, Tetraodon and stickleback. The assembly data available in the databases for Fugu and Tetraodon are not complete enough to provide solid confirmation for the absence of KiSS-1 in these species, as the genes surrounding KiSS-1 in other vertebrates are in these species spread in different scaffolds. However, for stickleback we found in the linkage group XVII (LGXVII) a genomic region syntenic to that of medaka KiSS-1 region in Chr5. Thus, we suggest that KiSS-1 may have been lost in stickleback. Another interesting finding is the absence of both KiSS-1 and KiSS-2 genes in the avian lineage. At present, searches in the chicken genome databases have failed to identify these genes. Nevertheless, regions in chicken Chr26 and Chr1 are syntenic to chromosomal regions containing KiSS-1 or KiSS2 , respectively, in other vertebrates. Thus, it is tenable that the avian lineage might have lost both genes, and likely their cognate receptor GPR54, as genomic searches have failed in its identification in this lineage. Yet, this taxonomic group conserves the major downstream targets of kisspeptin signaling (GnRHs, GnRH receptors and LH and FSH hormones) that are pivotal in controlling reproduction in poultry (Proudman et al., 2006). Of note, the gonadotropin-inhibitory peptide $(\mathrm{GnIH})$, which - as is the case for kisspeptins- belongs to the family of RF-amide peptides but conducts strong inhibitory actions on the gonadotropic axis, has been proposed to play a prominent regulatory role in avian reproduction (Tsutsui et al., 2007). Whether emergence of $\mathrm{GnIH}$ and the putative loss of KiSS genes in this taxa are evolutionary related merits further investigation.

The expression of KiSS-1 and KiSS-2 in the brain and the gonads of sea bass, medaka and zebrafish is fully compatible with their putative roles in the control of reproduction in fish. The expression of KiSS-1 in fish brain is in line with analogous findings in mammals, demonstrating its conserved expression in the CNS across vertebrate species (Roa et al., 2008; for review). KiSS-1 expression has been also reported in gonads and pituitary in mammals (Murphy, 2005). We readily detected KiSS-1 and KiSS-2 mRNAs in the testis and ovary of male and female fish. Yet, we were unable to demonstrate KiSS-1 and KiSS-2 mRNA expression in sea bass pituitary. As previously reported for KiSS-1 in mammals, KiSS-1 and KiSS-2 genes were also found to be expressed in other tissues in fish, although their functions at those sites remain unknown (Castellano et al., 2006a; Mead et al., 2007; Roa et al., 2008). In this context, it is noticeable the expression of $z$ fKiSS -1 in intestine, in agreement with recent studies (Biran et al., 2008; van Aerle et al., 2008). Overall, such spread expression of the elements of the KiSS system is suggestive of additional functional roles, other than the control of reproduction, in vertebrate species (Roa et al., 2008); a phenomenon that is yet to be fully characterized.

Comparative genomic analyses were combined with in vivo functional tests, evaluating the gonadotropin releasing capacity of sea bass kisspeptins in homologous and heterologous (rat) species. The former was considered mandatory in order to prove the potential involvement of both kisspeptins in the regulation of gonadotropin secretion (and hence, gonadal function) in fish. The latter may be informative also from an evolutionary stand-point, and might provide further clues on the structure-function relationships of mammalian kisspeptins. Testing of the LH and FSH releasing abilities of the nonmammalian counterparts of GnRH, such as the chicken, salmon and lamprey forms, has been previously used to evaluate the mechanisms for the differential control of gonadotropin secretion in mammals (Yu et al., 1997). Our analyses evidenced that both 
sbsKiSS-1 and sbsKiSS-2 peptides might play a role in the control of gonadotropin secretion in teleosts. However, when relative potencies of these peptides were compared, it became evident that the KiSS-2 peptide is a much more potent elicitor of gonadotropin secretion than KiSS-1 peptide in fish. Thus, despite conservation between mammalian kisspeptin-10 and teleost KiSS-1 peptide, the product of KiSS-2, whose predicted decapeptide shares only $60 \%$ homology with its mammalian counterpart, might be actually playing a dominant role in the control of gonadotropic axis, at least in sea bass. Of note also, sbsKiSS-2 peptide was able to elicit only marginal LH responses after i.c.v. administration to rats, where it was devoid of any detectable FSH-releasing capacity. These results are in contrast with the robust effects of KiSS-1 peptide on LH and, to a lesser extent, FSH secretion in rats, in keeping with previous references (Matsui et al., 2004; Roa et al., 2008). Overall, those observations are in agreement with the lack of KiSS-2 in the genome of placental mammals, and point out the importance of the 3 substituted amino acids at the N-terminal half of Kp-10/KiSS-1 peptide for proper GPR54 activation and subsequent GnRH secretion in mammals.

The differential gonadotropin responses described above in homologous and heterologous species are in line with recent findings obtained in vitro for the bullfrog (Moon et al., 2008), zebrafish (Biran et al., 2008) and human GPR54 receptors (Biran et al., 2008; Moon et al., 2008), where differential ligand selectivity for GPR54s was unveiled. In the case of bullfrog, synthetic Xenopus kisspeptin, which actually corresponds to the sbsKiSS-2 peptide, showed a higher potency than mammalian kisspeptin (identical to sbsKiSS-1 peptide) in the activation of bullfrog GPR54, whereas human GPR54 was preferentially activated by mammalian Kp-10 (Moon et al., 2008). In another study, zebrafish amidated kisspeptin, corresponding to the sbsKiSS-1 form, potently activated human GPR54, but had little effect on the zebrafish kisspeptin receptor (Biran et al., 2008). Altogether, those observations reinforce our hypothesis that a second KiSS-2/kisspeptin co-exists in non-placental vertebrates, which seems to be more effective in terms of GPR54 activation and stimulation of gonadotropin secretion than KiSS-1 in these species.

The wealth of genomic, expression and functional data reported herein for KiSS-1 and KiSS-2 show that they have similar gene and protein structures, analogous expression patterns, and coincident functional activities (albeit with different bio-potencies). These observations, together with the fact that the chromosomic regions of both genes contain several paralogs in different species, which are co-orthologues of a single gene in invertebrate chordates, lead us to propose that KiSS-1 and KiSS-2 might be originated from a single ancestor gene, which was duplicated in the first round of whole-genome duplication occurring more than 525 million years ago, before vertebrate radiation (Meyer and Van de Peer, 2005; Nakatani et al., 2007). According to this view, KiSS-1 and KiSS-2 would be paralogous genes. Different functional fates have been proposed for paralogs appearing after gene duplication (Hurles, 2004). In many cases, one of the paralogs is functionally lost becoming a pseudogene (non-functionalization). Less often, one of the copies acquires a new function while the other preserves the ancestral one (neo-functionalization). In a third scenario, both paralogs lose a different subset of functions, complementing each other to fulfill the ancestral one (sub-functionalization). With the data available so far, we propose that the two KiSS genes could have had divergent fates in the different lineages. A non-functionalization process could be 
proposed for those species lacking one of the two genes. In the case of sea bass, the expression patterns of KiSS-1 and KiSS-2 evidence an evolution in parallel, although comparative functional analyses support the hypothesis that KiSS-2 peptide is a more active kisspeptin form in fish. This could point to a sub-functionalization or redundant function for sea bass paralogs. In any case, further research is needed to understand which driving forces led to these different fates in vertebrates. Moreover, whether evolutionary relationships exist between the number of KiSS genes and the presence of certain forms of its downstream effector GnRH would deserve a deeper analysis, to better understand the regulation of the gonadotropic axis.

In conclusion, we provide herein the first evidence for the co-existence of two KiSS genes, namely KiSS-1 and KiSS-2, in the genome of non-placental vertebrates. The predicted decapeptides derived from those genes show distinct gonadotropin-releasing activities in fish and mammals, with KiSS-2 peptide being a more potent elicitor of gonadotropin secretion in the fish species, sea bass. These data add further strength to the pivotal role of kisspeptins in the control of vertebrate reproduction, and illustrate the complex evolutionary process of this neuroendocrine system. 


\section{Acknowledgements.}

We thank Conrado Marín for his technical assistance rearing and sampling the fish at IATS facilities, and Soledad Ibáñez and Xavier Beltrán for their assistance with hormonal analysis in fish samples. We would also like to thank Prof. Manfred Schartl for his advice and support. This work was financially supported by Generalitat Valenciana (GV06/268) to A.G and grant BFU2008-00984 from Ministerio de Ciencia e Innovación (Spain) to M.T.-S. A.F. was supported by a Ramón y Cajal contract from the Ministry of Education and Science of Spain. 


\section{References}

Biran, J., Ben-Dor, S., Levavi-Sivan, B., 2008. Molecular identification and functional characterization of the kisspeptin/kisspeptin receptor system in lower vertebrates. Biol. Reprod. 79, 776-786.

Briant, C., Schneider, J., Guillaume, D., Ottogalli, M., Duchamp, G., Bruneau, B., Caraty, A., 2006. Kisspeptin induces ovulation in cycling Welsh pony mares. Anim. Reprod. Sci. 94, 217-219.

Brown, R.E., Imran, S.A., Wilkinson, E.Ur.M., 2008. KiSS-1 mRNA in adipose tissue is regulated by sex hormones and food intake. Mol. Cell. Endocrinol. 281, 64-72.

Castellano, J.M., Gaytan, M., Roa, J., Navarro, V.M., Bellido, C., Dieguez, C., Aguilar, E., Sánchez-Criado, J.E., Pellicer, A., Pinilla, L., Gaytan, F., Tena-Sempere, M., 2006a. Expression of KiSS-1 in rat ovary: putative local regulator of ovulation?. Endocrinology 147, 4852-4862.

Castellano, J.M., Navarro, V.M., Fernández-Fernández, R., Castaño, J.P., Malagón, M.M., Aguilar, E., Dieguez, C., Magni, P., Pinilla, L., Tena-Sempere, M., 2006b. Ontogeny and mechanisms of action for the stimulatory effect of kisspeptin on gonadotropin-releasing hormone system of the rat. Mol. Cell. Endocrinol. 257$258,75-83$.

Castellano, J.M., Navarro, V.M., Fernández-Fernández, R., Roa, J., Vigo, E., Pineda, R., Dieguez, C., Aguilar, E., Pinilla, L., Tena-Sempere, M., 2006c. Expression of hypothalamic KiSS-1 system and rescue of defective gonadotropic responses by kisspeptin in streptozotocin-induced diabetic male rats. Diabetes 55, 2602-2610.

Castellano, J.M., Roa, J., Luque, R.M., Dieguez, C., Aguilar, E., Pinilla, L., TenaSempere, M., 2008. KiSS-1/Kisspeptins and the metabolic control of reproduction; physiologic roles and putative physiopathological implications. Peptides DOI: 10.1016/j.peptides.2008.06.007

Colledge, W.H., 2004. GPR54 and puberty. Trends Endocrinol. Metab. 15, 448-453.

de Roux, N., Genin, E., Carel, J.C., Matsuda, F., Chaussain, J.L., Milgrom, E., 2003. Hypogonadotropic hypogonadism due to loss of function of the KiSS1-derived peptide receptor GPR54. Proc. Natl. Acad. Sci. U.S.A. 100, 10972-10976.

Dhillo, W.S., Chaudhri, O.B., Patterson, M., Thompson, E.L., Murphy, K.G., Badman, M.K., McGowan, B.M., Amber, V., Patel, S., Ghatei, M.A., Bloom, S.R., 2005. Kisspeptin-54 stimulates the hypothalamic-pituitary-gonadal axis in human males. J. Clin. Endocrinol. Metab. 90, 6609-6615.

Dungan, H.M., Clifton, D.K., Steiner, R.A., 2006. Minireview: Kisspeptin neurons as central processors in the regulation of gonadotropin-releasing hormone secretion. Endocrinology 147, 1154-1158.

Fernández-Fernández, R., Martín, A.C., Navarro, V.M., Castellano, J.M., Dieguez, C., Aguilar, E., Pinilla, L., Tena-Sempere, M., 2006. Novel signals for the integration of energy balance and reproduction. Mol. Cell. Endocrinol. 254-255, 127-132.

Filby, A.L., van Aerle, R., Duitman, J.W., Tyler, C.R., 2008. The kisspeptin/gonadotropin-releasing hormone pathway and molecular signaling of puberty in fish. Biol. Reprod. 78, 278-289. 
Gottsch, M.L., Clifton, D.K., Steiner, R.A., 2006. Kisspeptin-GPR54 signalling in the neuroendocrine reproductive axis. Mol. Cell. Endocrinol. 254-255, 91-96.

Hofmann, H.A., 2006. Gonadotropin-releasing hormone signalling in behavioral plasticity Curr. Opin. Neurobiol. 16, 343-350.

Horikoshi, Y., Matsumoto, H., Takatsu, Y., Ohtaki, T., Kitada, C., Usuki, S., Fujino, M., 2003. Dramatic elevation of plasma metastin concentrations in human pregnancy: metastin as a novel placenta-derived hormone in humans. J. Clin. Endocrinol. Metab. 88, 914-919.

Hules, M. 2004. Gene duplication: The genomic trade in spare parts. PloS Biol. 2, 900904.

Kaiser, U.B., Kuohung, W., 2005. KiSS-1 and GPR54 as new players in gonadotropin regulation and puberty. Endocrine 26, 277-284.

Kanda, S., Akazome, Y., Matsunaga, T., Yamamoto, N., Yamada, S., Tsukamura, H., Maeda, K., Oka, Y., 2008. Identification of KiSS-1 product kisspeptin and steroid-sensitive sexually-dimorphic kisspeptin neurons in medaka (Oryzias latipes). Endocrinology 149, 2467-2476.

Kinoshita, M., Tsukamura, H., Adachi, S., Matsui, H., Uenoyama, Y., Iwata, K., Yamada, S., Inoue, K., Ohtaki, T., Matsumoto, H., Maeda, K.I., 2005. Involvement of central metastin in the regulation of preovulatory LH surge and estrous cyclicity in female rats. Endocrinology 146, 4431-4436.

Luque, R.M., Kineman, R.D., Tena-Sempere, M., 2007. Regulation of hypothalamic expression of KiSS-1 and GPR54 genes by metabolic factors: Analyses using mouse models and a cell line. Endocrinology 148, 4601-4611.

Mateos, J., Mañanós, E., Swanson, P., Carrillo, M., Zanuy, S., 2006. Purification of luteinizing hormone (LH) in the sea bass (Dicentrarchus labrax L.) and development of specific immunoassay (ELISA). Cienc. Mar. 32, 271-283.

Matsui, H., Takatsu, Y., Kumano, S., Matsumoto, H., Ohtaki, T., 2004. Peripheral administration of metastin induces marked gonadotropin release and ovulation in the rat. Biochem. Biophys. Res. Commun. 320, 383-388.

Mead, E.J., Maguire, J.J., Kuc, R.E., Davenport, A.P., 2007. Kisspeptins are novel potent vasoconstrictors in humans, with a discrete localization of their receptor, $\mathrm{G}$ protein-coupled receptor 54, to atherosclerosis-prone vessels. Endocrinology 148, 140-147.

Mechaly, A.S., Viñas, J., Piferrer, F., 2008. Identification of Two Isoforms of the Kisspeptin-1 Receptor (kiss1r) Generated by Alternative Splicing in a Modern Teleost, the Senegalese Sole (Solea senegalensis). Biol. Reprod. DOI:10.1095/biolreprod.108.072173.

Messager, S., Chatzidaki, E.E., Ma, D., Hendrick, A.G., Zahn, D., Dixon, J., Thresher, R.R., Malinge, I., Lomet, D., Carlton, M.B.L., Colledge, W.H., Caraty, A., Aparicio, S.A.JR. 2005. Kisspeptin directly stimulates gonadotropin-releasing hormone release via $\mathrm{G}$ protein-coupled receptor 54. Proc. Natl. Acad. Sci. U.S.A. 102, 1761-1766.

Meyer, A., Van de Peer, Y., 2005. From 2R to 3R: evidence for a fish-specific genome duplication (FSGD). Bioessays 27, 937-945. 
Mohamed, J.S., Benninghoff, A.D., Holt, G.J., Khan, I.A., 2007. Developmental expression of the G protein-coupled receptor 54 and three GnRH mRNAs in the teleost fish cobia. J. Mol. Endocrinol. 38, 235-244.

Molés, G., Gómez, A., Rocha, A., Carrillo, M., Zanuy, S., 2008. Purification and characterization of follicle-stimulating hormone from pituitary glands of sea bass (Dicentrarchus labrax). Gen. Comp. Endocrinol. 158, 68-76.

Moon, J.S., Lee, Y.R., Oh, D.Y., Hwang, J.I., Lee, J.Y., Kim, J.I., Vaudry, H., Kwon, H.B., Seong, J.Y., 2008. Molecular cloning of the bullfrog kisspeptin receptor GPR54 with high sensitivity to Xenopus kisspeptin. Peptides DOI: 10.1016/j.peptides.2008.04.015

Murphy, K.G., 2005. Kisspeptins: Regulators of metastasis and the hypothalamicpituitary-gonadal axis. J. Neuroendocrinol. 17, 519-525.

Nakatani, Y., Takeda, H., Kohara, Y., Morishita, S., 2007. Reconstruction of the vertebrate ancestral genome reveals dynamic genome reorganization in early vertebrates. Genome Res. 17, 1254-1265.

Navarro, V.M., Castellano, J.M., Fernández-Fernández, R., Barreiro, M.L., Roa, J., Sanchez-Criado, J.E., Aguilar, E., Dieguez, C., Pinilla, L., Tena-Sempere, M., 2004a. Developmental and hormonally regulated messenger ribonucleic acid expression of KiSS-1 and its putative receptor, GPR54, in rat hypothalamus and potent luteinizing hormone-releasing activity of KiSS-1 peptide. Endocrinology $145,4565-4574$.

Navarro, V.M., Castellano, J.M., Fernández-Fernández, R., Tovar, S., Roa, J., Mayen, A., Barreiro, M.L., Casanueva, F.F., Aguilar, E., Dieguez, C., Pinilla, L., TenaSempere, M., 2005a. Effects of KiSS-1 peptide, the natural ligand of GPR54, on follicle-stimulating hormone secretion in the rat. Endocrinology 146, 1689-1697.

Navarro, V.M., Castellano, J.M., Fernández-Fernández, R., Tovar, S., Roa, J., Mayen, A., Nogueiras, R., Vazquez, M.J., Barreiro, M.L., Magni, P., Aguilar, E., Dieguez, C., Pinilla, L., Tena-Sempere, M., 2005b. Characterization of the potent luteinizing hormone-releasing activity of KiSS-1 peptide, the natural ligand of GPR54. Endocrinology 146,156-163.

Navarro, V.M., Fernández-Fernández, R., Castellano, J.M., Roa, J., Mayen, A., Barreiro, M.L., Gaytan, F., Aguilar, E., Pinilla, L., Dieguez, C., Tena-Sempere, M., 2004b. Advanced vaginal opening and precocious activation of the reproductive axis by KiSS-1 peptide, the endogenous ligand of GPR54. J. Physiol. 561, 379-386.

Nocillado, J.N., Levavi-Sivan, B., Carrick, F., Elizur, A., 2007. Temporal expression of G-protein-coupled receptor 54 (GPR54), gonadotropin-releasing hormones $(\mathrm{GnRH})$, and dopamine receptor D2 (drd2) in pubertal female grey mullet, Mugil cephalus. Gen. Comp. Endocrinol. 150, 278-287.

Okuzawa, K., 2002. Puberty in teleosts. Fish Physiol. Biochem. 26, 31-41.

Parhar, I.S., Ogawa, S., Sakuma, Y., 2004. Laser-captured single digoxigenin-labeled neurons of gonadotropin-releasing hormone types reveal a novel $\mathrm{G}$ proteincoupled receptor (Gpr54) during maturation in cichlid fish. Endocrinology 145, 3613-3618.

Plant, T.M., Ramaswamy, S., DiPietro, M.J., 2006. Repetitive activation of hypothalamic GPR54 with intravenous pulses of kisspeptin in the juvenile monkey (Macaca 
mulatta) elicits a sustained train of GnRH discharges Endocrinology 147, 10071013.

Proudman, J.A., Scanes, C.G., Johannsen, S.A., Berghman, L.R., Camp, M.J., 2006. Comparison of the ability of the three endogenous GnRHs to stimulate release of follicle-stimulating hormone and luteinizing hormone in chickens. Domest. Anim. Endocrinol. 31, 141-153.

Roa, J., Aguilar, E., Dieguez, C., Pinilla, L., Tena-Sempere, M., 2008. New frontiers in kisspeptin/GPR54 physiology as fundamental gatekeepers of reproductive function. Front. Neuroendocrinol. 29, 48-69.

Roa, J., Tena-Sempere, M., 2007. KiSS-1 system and reproduction: Comparative aspects and roles in the control of female gonadotropic axis in mammals. Gen. Comp. Endocrinol. 153, 132-140.

Rocha, A., Gómez, A., Zanuy, S., Cerdá-Reverter, J.M., Carrillo, M., 2007. Molecular characterization of two sea bass gonadotropin receptors: cDNA cloning, expression analysis, and functional activity. Mol. Cell. Endocrinol. 272, 63-76.

Seminara, S.B., 2005. Metastin and its G protein-coupled receptor, GPR54: Critical pathway modulating GnRH secretion. Front. Neuroendocrinol. 26, 131-138.

Seminara, S.B., Kaiser, U.B., 2005. New gatekeepers of reproduction: GPR54 and its cognate ligand, KiSS-1. Endocrinology 146, 1686-1688.

Seminara, S.B., Messager, S., Chatzidaki, E.E., Thresher, R.R., Acierno, J.S., Shagoury, J.K., Bo-Abbas, Y., Kuohung, W., Schwinof, K.M., Hendrick, A.G., Zahn, D., Dixon, J., Kaiser, U.B., Slaugenhaupt, S.A., Gusella, J.F., O’Rahilly, S., Carlton, M.B.L., Crowley, W.F., Aparicio, S.A., Colledge, W.H., 2003. The GPR54 gene as a regulator of puberty. N. Engl. J. Med. 349, 1614-1627.

Shahab, M., Mastronardi, C., Seminara, S.B., Crowley, W.F., Ojeda, S.R., 2005. Increased hypothalamic GPR54 signaling: A potential mechanism for initiation of puberty in primates. Proc. Natl. Acad. Sci. U.S.A. 102, 2129-2134.

Shibata, M., Friedman, R.L., Ramaswamy, S., Plant, T.M., 2007. Evidence that down regulation of hypothalamic KiSS-1 expression is involved in the negative feedback action of testosterone to regulate luteinising hormone secretion in the adult male rhesus monkey (Macaca mulatta). J. Neuroendocrinol. 19, 432-438.

Smith, J.T., 2008. Kisspeptin signalling in the brain: Steroid regulation in the rodent and ewe. Brain Res. Rev. 57, 288-298.

Smith, J.T., Acohido, B.V., Clifton, D.K., Steiner, R.A., 2006a. KiSS-1 neurones are direct targets for leptin in the ob/ob mouse. J. Neuroendocrinol. 18, 298-303.

Smith, J.T., Clay, C.M., Caraty, A., Clarke, I.J., 2006b. KiSS-1 messenger ribonucleic acid expression in the hypothalamus of the ewe is regulated by sex steroids and season. Endocrinology 148, 1150-1157.

Smith, J.T., Dungan, H.M., Stoll, E.A., Gottsch, M.L., Braun, R.E., Eacker, S.M., Clifton, D.K., Steiner, R.A., 2005. Differential regulation of KiSS-1 mRNA expression by sex steroids in the brain of the male mouse. Endocrinology 146, 2976-2984.

Sokal, R.R., Rohlf, F.J., 1981. Biometry. The principles and practice of statistics in biological research ( $2^{\text {nd }}$ edn). pp 859, W.H. Freeman, NY.

Tamura, K., Dudley, J., Nei, M., Kumar, S., 2007. MEGA4: Molecular Evolutionary Genetics Analysis (MEGA) software version 4.0. Mol. Biol. Evol. 24, 1596-1599. 
Thompson, J.D., Gibson, T.J., Plewniak, F., Jeanmougin, F., Higgins, D.G., 1997. The CLUSTAL X windows interface: flexible strategies for multiple sequence alignment aided by quality analysis tools. Nucleic Acids Res. 25, 4876-4882.

Thompson, E.L., Patterson, M., Murphy, K.G., Smith, K.L., Dhillo, W.S., Todd, J.F., Ghatei, M.A., Bloom, S.R., 2004. Central and peripheral administration of kisspeptin-10 stimulates the hypothalamic-pituitary-gonadal axis. J. Neuroendocrinol. 16, 850-858.

Tsutsui, K., Bentley, G.E., Ubuka, T., Saigoh, E., Yin, H., Osugi, T., Inoue, K., Chowdhury, V.S., Ukena, K., Ciccone, N., Sharp, P.J., Wingfield, J.C., 2007. The general and comparative biology of gonadotropin-inhibitory hormone $(\mathrm{GnIH})$. Gen. Comp. Endocrinol. 153, 365-70.

van Aerle, R., Kille, P., Lange, A., Tyler, C.R., 2008. Evidence for the existence of a functional Kiss1/Kiss1 receptor pathway in fish. Peptides 29, 57-64.

Weltzien, F.A., Andersson, E., Andersen, Ø., Shalchian-Tabrizi, K., Norberg, B., 2004. The brain-pituitary-gonad axis in male teleosts, with special emphasis on flatfish (Pleuronectiformes). Comp. Biochem. Physiol. A 137, 447-477.

Yu, W.H., Karanth, S., Walczewska, A., Sower, S.A., McCann, S.M., 1997. A hypothalamic follicle-stimulating hormone-releasing decapeptide in the rat. Proc. Natl. Acad. Sci. U.S.A. 94, 9499-9503. 


\section{Figure legends}

Figure 1. Comparison of vertebrate KiSS-1 and KiSS-2 genes. (A) Nucleotide sequences of sea bass KiSS-1 and KiSS-2 cDNAs. Deduced amino acids are shown above the sequence. Signal peptides were predicted at the Center for Biological Sequence (CBS) Analysis (http://www.cbs.dtu.dk/services/) using SignalP 3.0 (Signal1P-HMM). The putative kisspeptin-10 sequences are shaded. The nucleotide sequences have been submitted to the GenBank and are available under the Accession Nos. FJ008914 for sbsKiSS-1 and $\underline{\mathbf{F J 0 0 8 9 1 5}}$ for sbsKiSS-2. Arrowheads mark the exon-intron junctions. (B) Sequence alignment of deduced amino acid sequences of vertebrate KiSS-1 and KiSS-2 genes. The amino acid residues conserved in all species are shaded in black, those conserved in $70 \%$ and $50 \%$ of the species are shaded in grey and light grey, respectively. The kisspeptin-10 region for each KiSS gene is indicated. Sequences for rat (AY196983), mouse, (AB162440), human (AY117143), medaka (AB272755) and zebrafish (AB245404) KiSS-1 cDNAs were retrieved from the GenBank. The rest of the sequences in the alignments were deduced from genomic data downloaded from the Ensembl Genome Browser (see legend Fig. 3). Coding sequences were predicted with HMMGene (v. 1.1) at CBS and GeneView2. For Xenopus KiSS-1 and stickleback KiSS-2 only the amino acids from the predicted exon 2 are shown.

Figure 2. Phylogenetic analysis and genomic organization of vertebrate KiSS-1 and KiSS2 genes. (A) Neighbor-joining bootstrap consensus tree. Bootstrap values (\%) from 10000 replicates are indicated for each tree node. An alignment of amino acid sequences corresponding to exon 2 was used to generate the tree. Ambiguously aligned sequences and gaps were removed before phylogenetic analysis. (B) Synteny of KiSS-1 containing regions in vertebrate genomes. In mouse and rat the proximity between KiSS-1 and GOLT1A (number 7) indicates that the sequence of KiSS-1 was found within GOLT1A. Those genes boxed in human $\mathrm{Chr} 1$ are located in other chromosomes in that species. (C) Synteny of KiSS-2 containing regions in vertebrate genomes. Those genes boxed in mouse and rat are located in the indicated chromosome. In both schematic representations, not to scale, numbers on the boxes (and colour coding) indicate different genes, whose names are shown above. Orthologous genes are represented as a square, and those cases where paralogs were found in KiSS-1 and KiSS-2 analyzed regions are represented as an oval form. A black bar between genes indicates that these are not contiguous. Dashed boxes for KiSS-1or KiSS-2 represent absence of the gene. Numbers in brackets on the right indicate which chromosome $(\mathrm{Ch})$, scaffold $(\mathrm{S})$ or linkage group (LG) the cluster is found on. The gene searches were done at Ensembl against the genome assemblies of human (Hs) (Homo sapiens) (assembly NCBI 36), mouse (Mm) (Mus musculus), rat (Rn) (Rattus norvegicus) (assembly RGSC 3.4), opossum (Md) (Monodelphis domestica) (assembly MonDom 5), platypus (Ornithorhynchus anatinus) (assembly Ornithorhynchus_anatinus-5.0), chicken (Gg) (Gallus gallus) (assembly WASHUC2), lizard (Anolis carolinensis) (assembly AnoCar1.0), Xenopus (Xenopus tropicalis) (assembly Version 4.1), medaka (Ol) (Oryzias latipes) (assembly Zv7), zebrafish (Dr) (Danio rerio) (assembly Zv7), Fugu (Fr) (Fugu rubripes) (Ensembl 49), Tetraodon (Tn) (Tetraodon nigroviridis) (assembly Version 8), stickleback (Ga) (Gasterosteus aculeatus) (assembly BROAD S1) and sea lamprey (Petromyzon marinus) 
(assembly 5.9X). Gene name abbreviations: SOX13 (SRY-box containing gene 13), ETNK2 (ethanolamine kinase 2), REN (renin), GOLT1A (golgi transport 1 homolog A), PLEKHA6 (pleckstrin homology domain containing, family A member 6), PIK3C2B (phosphoinositide-3-kinase, class 2, beta polypeptide), PPP1R15B (protein phosphatase 1, regulatory (inhibitor) subunit 15b), OVGP1 (oviductal glycoprotein 1), CACNA1S (calcium channel, voltage-dependent, $\mathrm{L}$ type, alpha $1 \mathrm{~S}$ subunit), APOBEC2 (apolipoprotein B mRNA editing enzyme, catalytic polypeptide-like 2), ARFRP1 (ADPribosylation factor regulated protein 1), $P P A R$ (peroxisome proliferator activated receptor alpha), $L D H B$ (lactate dehydrogenase B), SLC25A3 (solute carrier family 25), TMPO (thymopoietin), STRAP (serine threonine receptor-associated protein), GYS2 (glycogen synthase 2), C12orf39 (chromosome 12 open reading frame 39), GOLT1B (golgi transport 1 homolog $\mathrm{B}$ ), PIK3CG (phosphoinositide-3-kinase, catalytic, gamma polypeptide), PLEKHA5 (pleckstrin homology domain containing, family A member 5), RECQL (RecQ protein-like), KCNJ8 (potassium inwardly-rectifying channel, subfamily J, member 8), ABCC9 (ATP-binding cassette, subfamily C (CFTR/MRP), member 9), ETNK1 (ethanolamine kinase 1) and BICD1 (protein bicaudal D homolog 1).

Figure 3. RT-PCR analysis of sea bass KiSS-1 and KiSS-2 genes. (A) Expression in adult and juvenile fish tissues from male and female sea bass in January $(\mathrm{n}=3-5$ pooled tissues) (B) Expression in gonads (testis and ovary) and brain in adult and juvenile fish during the reproductive period (January, J; February, F; March, M and April, A). Total RNA extracted from 2 (in $\mathrm{M}$ and $\mathrm{A}$ ) or 3 (in F) pooled tissues at each month was reversetranscribed and amplified by PCR except for gonad and brain from one fish in J that was used individually for RT-PCR. sbsefl $\alpha$ was used as an internal control to verify the integrity of the RNAs. $\mathrm{C}^{-}$: negative control for PCR which was performed using sterile water as template.

Figure 4. RT-PCR analysis of medaka and zebrafish KiSS-1 and KiSS-2 expression in tissues from male and female adult fish. Total RNA extracted from 3-6 pooled tissues was reverse-transcribed and amplified by PCR. mdefl $\alpha$ and zfefl $\alpha$ were used as an internal control to verify the integrity of the RNAs. $\mathrm{C}^{-}$: negative control for PCR which were performed with sterile water as template.

Figure 5. Analysis of the effects of intramuscular administration of sbsKiSS-1 and sbsKiSS-2 peptides on LH (A) and FSH (B) secretion over a 240-min period in prepubertal 1-year-old sea bass. (C) LH secretion over a 240-min period in pubertal 2years-old male sea bass. In all cases, vehicle-injected groups (PBS) served as controls. Hormonal values are the mean \pm SEM of 5-10 independent determinations. LH levels are presented as percentage of the basal levels of animals at 0 min before injection. FSH levels are presented as percentage of RLU over unstimulated cells. $(*) P<0.05$.

Figure 6. Analysis of the effects of central (i.c.v.; 100 pmol/rat) and systemic (i.p.; 15 $\mu \mathrm{g} / \mathrm{rat}$ ) administration of sbsKiSS-1 and sbsKiSS-2 peptides on LH (A-B) and FSH (C-D) secretion over a 120 -min period in adult male rats. Hormonal values are the mean \pm SEM of 10 independent determinations. $\left(^{*}\right) P<0.05$. 
Table 1. Gene-specific primers ${ }^{1}$ used for RT-PCR analysis

\begin{tabular}{|c|c|c|c|c|}
\hline Gene & Species & $\begin{array}{l}\text { Primer } \\
\text { direction }\end{array}$ & 5 'to $3^{\prime}$ sequence & $\begin{array}{c}\text { Fragment } \\
\text { size (bp) }\end{array}$ \\
\hline \multirow[t]{6}{*}{ KiSS-1 } & \multirow[t]{2}{*}{ Sea bass } & Sense & CTCATTGTCGCTCTGATGATAGC & \multirow[t]{2}{*}{212} \\
\hline & & Antisense & GGACACATCTTGACGTTTCTTGATAG & \\
\hline & \multirow{2}{*}{ Medaka } & Sense & CTGTGTTGGCACAGGTGTGGAC & \multirow{2}{*}{263} \\
\hline & & Antisense & TTTTCCATAACGGAGACCAAAAGAG & \\
\hline & \multirow[t]{2}{*}{ Zebrafish } & Sense & TGCTTACTGTCATATTGATGTTGTCA & \multirow[t]{2}{*}{357} \\
\hline & & Antisense & ACAGGACTTTTCTGTTTCAATCGTG & \\
\hline \multirow[t]{6}{*}{ KiSS-2 } & \multirow[t]{2}{*}{ Sea bass } & Sense & ACTCCTGCGGTCGTTGCACAGG & \multirow[t]{2}{*}{189} \\
\hline & & Antisense & ATGAGGCTCGTGGCTCTGGTCGT & \\
\hline & \multirow[t]{2}{*}{ Medaka } & Sense & CTCGTGCTGTGCGCGCTGATC & \multirow[t]{2}{*}{320} \\
\hline & & Antisense & ACCTCCTGAAACAGGGACATCAG & \\
\hline & \multirow{2}{*}{ Zebrafish } & Sense & АTTCTCTTCATGTCTGCAATGGTCA & \multirow{2}{*}{344} \\
\hline & & Antisense & TGCTTTCTCAGGTAAAGCATCATTG & \\
\hline \multirow[t]{6}{*}{ efl $\alpha$} & \multirow[t]{2}{*}{ Sea bass } & Sense & CTTACAGCCAGGCCCGCT & \multirow[t]{2}{*}{289} \\
\hline & & Antisense & GTCTCCACACGACCGACG & \\
\hline & \multirow[t]{2}{*}{ Medaka } & Sense & CTTACAGCCAGGCCCGTTT & \multirow[t]{2}{*}{287} \\
\hline & & Antisense & GTCTCAACACGGCCGACAG & \\
\hline & \multirow[t]{2}{*}{ Zebrafish } & Sense & CTTACAGCCAGGCTCGTTT & \multirow[t]{2}{*}{287} \\
\hline & & Antisense & AGTCTCCACACGACCCACA & \\
\hline
\end{tabular}

${ }^{\mathrm{T}}$ All primer pairs were designed in different exons to exclude false positive bands in case of potential genomic DNA contamination 


\title{
A Sea bass KiSS-1
}

\begin{abstract}
1 GGCACGAGCTCTCTCTCTCTCTCTCTCTCTCTCTCTCTCTCTCTCTCTCTCTCTCTCTCTCTCCTCAGTCAGCACTCGCCTTCAGCACACCGAGGAATT $\begin{array}{llllllllllllllllllllllllllll}1 & \boldsymbol{M} & \boldsymbol{P} & \boldsymbol{R} & \boldsymbol{L} & \boldsymbol{I} & \boldsymbol{V} & \boldsymbol{A} & \boldsymbol{L} & \boldsymbol{M} & \boldsymbol{I} & \boldsymbol{A} & \boldsymbol{A} & \boldsymbol{L} & \boldsymbol{S} & \boldsymbol{T} & \boldsymbol{E} & \boldsymbol{I} & \boldsymbol{Y} & \boldsymbol{N} & \boldsymbol{T} & \mathrm{S} & \mathrm{M} & \mathrm{I} & \mathrm{S} & \mathrm{S} & \mathrm{Y} & \mathrm{H}\end{array}$ 100 TCAGCAGGTCTGTCACGATGCCCCGACTCATTGTCGCTCTGATGATAGCTGCTTTGTCAACAGAGATCTACAACACCAGCATGATATCCAGCTACCACA

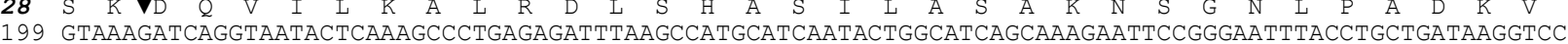

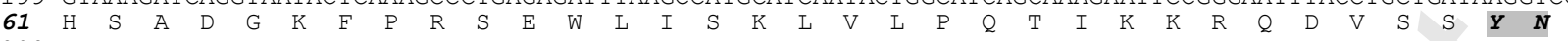
298 ATTCAGCTGATGGAAAGTTTCCCAGGTCAGAATGGTTGATCTCAAAGCTGGTCCTCCCTCAGACTATCAAGAAACGTCAAGATGTGTCCTCATACAACC $\begin{array}{lllllllllllll}94 & L & \boldsymbol{N} & \boldsymbol{S} & \boldsymbol{F} & \boldsymbol{G} & \boldsymbol{L} & \boldsymbol{R} & \boldsymbol{Y} & \mathrm{G} & \mathrm{K} & *\end{array}$

396 TCAACTCCTTTGGTCTACGTTACGGAAAGTGACACAAGACCTGATGTCTGTTGTTATTCTGTGTTAGAGCTGATATTTTTATATATTTTCTTTGTACAT 495 TCAGAGTGGGAAAAGAAAGTGTAATGTCACTGTTGAAAGCTCAATAAAAATGTTGGTTAAAGATT
\end{abstract}

\section{Sea bass KiSS-2}

$\begin{array}{llllllllllllllllllllllllllllllllllll}M & \boldsymbol{R} & \boldsymbol{L} & \boldsymbol{V} & \boldsymbol{A} & \boldsymbol{L} & \boldsymbol{V} & \boldsymbol{V} & \boldsymbol{V} & \boldsymbol{C} & \boldsymbol{G} & \boldsymbol{L} & \boldsymbol{I} & \boldsymbol{L} & \boldsymbol{G} & \mathrm{Q} & \mathrm{D} & \mathrm{G} & \mathrm{G} & \mathrm{S} & \mathrm{V} & \mathrm{G} & \mathrm{A} & \mathrm{A}\end{array}$ 25 GGCACGAGGAGACACACACACAGAGGATGAGGCTCGTGGCTCTGGTCGTGGTGTGCGGGCTGATCCTGGGTCAGGATGGAGGGAGCGTGGGAGCAGCTC $\begin{array}{llllllllllll} & & \end{array}$

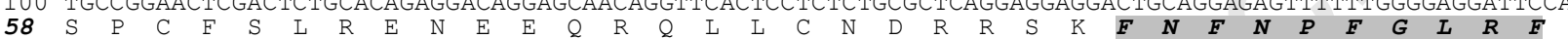
199 GCCCGTGTTTCTCTCTGAGAGAGAACGAGGAGCAGCGGCAGCTCCTGTGCAACGACCGCAGGAGTAAATTCAACTTCAACCCGTTCGGCCTCCGCTTCG $\begin{array}{lllllllllllllllllllllllllllllllllllll}91 & G & K & R & Y & I & Y & R & R & A & L & K & R & A & R & T & N & R & F & S & P & L & F & L & F & S & R & E & L & E & V & P & T & \& & \end{array}$ 298 GGAAGCGCTACATTTACAGAAGGGCCCTTAAAAGAGCCAGGACGAACAGGTTCTCGCCCCTTTTTCTCTTCTCACGAGAACTGGAGGTGCCTACCTGAT 396 GCCTACTGATGTGTCTTCCTCTGAGGACTTGTGTCCCATTGGTGAAAAGTCAACATGTGACAAGTCTTTCCATGTGTTTAAAATAGGCCTTTTACTTCA 495 GATAAAAGGTTTCGGTGAATTAAACTTTTTGTACCTACCTTTACTGTGACATGATTTGAACATGGAAGAATACGAGAGAAAAACACACTTACAACAGTG 595 TAAACAGAATGCTTTAGACAATATCATTTTGTAAAATGTTTGCTTTTCTCATCTCAGTTTTTAAGAAATCTAAATGAAACAGTCCAATGGACTTTTATG 694 ATGATGGaAAGGAGTAGTTCATTTCACAATAAAAGCACTGTATGGTTAAT

B $\underline{\text { KiSS-1 }}$

rat

mouse

human

opossum

platypus

Xenopus

seabas

medaka

zebrafish
lamprey

rat

mouse

human

opossum

platypus

Xenopus

seabass

medaka

zebrafish

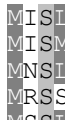

SIASWQ-LLLLLCVASFGEPLAKMAP-VVNPEPT---GQQSGPQELVNAWQKGPRYAESKP-GAAGLRA SMASWQ-LLLLLCVATYGEPLAK-----VKPGST---GQQSGPQELVNAWEKESRYAESKP-GSAGLRA LISWQ-LLLFLCATHFGEPLEKVAS-VGNSRPT---GQQLESLGLIAPGEQSLPCTERKP-AATARLSR 作 VLSLLCRRKKSLSTGHP 50 MPRLIVAL-MIAALSTEIYNTSMISS---YHSK--------DQVILKALRDLS----------HASILASAKNSGNLPADKVHSADGK 66 MAAPLIVAVIMWAVILAQVWTAHHRHQST-IHTE--------DNALLKMIRNFN-----------YLS--SSMKEWP--KSDR--SSDGG 63 -MMLLTVILMLSVARVHTNPSGHFQY-YLE-------DETPEETSLRVLRG--------------TDTRPTDGSPPSK--ISALF 60 MRGLTVVTFLFLVLCCDSFGKVVSFYG--FKESTKSGGGQLPGDVTDILREITS----------LLEGTDGIVAFYDFPGSGGSVDRAF 77

mpre

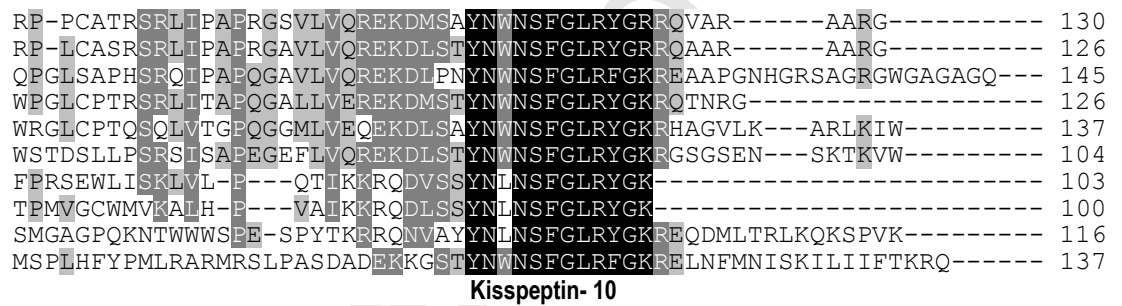

KiSS-2

platypus

lizard

Xenopus

zebrafish

seabass

stickleback

Fugu

Tetraodon

medaka

lamprey

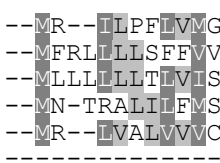

YQSGSLGNPLLGERKAVKRLEFTDVPAVIHAEAK-

-RGEQPAGQEAAAGPG

YLVEQGSRVQ------- 71 ILSPNGTFGKPVYGDFR--SILQVAFSDAADPANDLQAKRNSYTNTRESEVLDSEDPSSLCYFIQESETESQ------ 82 QHAVGGTMFR---GDEEGLELEEIGGPETSYPEGDPREKSESYELIPSADTLSWPGRSNICYFIREGRLESQ----- 81 SAMVSQSTAMRAILTDMDTPEPMPDPKPRF IS-----------MERRQFEEPSASDDASLCFFIQEKDETSQ------ 71 -- MR--VLVLILV-- LAVAPDRGG-----AHATMQVTGGSGS
-- MRLWVLVLILVRALTVAQDRGAT-----HHATVQGAGGPGS

LSA--------I
RRRTAGEF-FGEDSSPCFSLRENEEQRQ------ 71

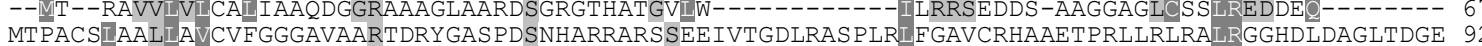
RRGTAGQLQLLQESNPCLTFRDNEDQ------- 60 RKGTVGEL-LLEESNPCVALRDNQDQ------- 64

platypus

lizard

Xenopus

zebrafish

seabass

stickleback

Fugu

Tetraodon

medaka

lamprey

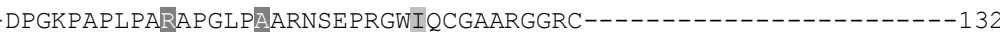
OGDTLADDGKLGSQGSRKI LQALLKPRLDQTHSQCGENWGDTC-ARGDANGEG-LAPLVPRRLLPFLLK----LKDKRCSESVGESC---------------------143 -NEATTSDSDRLKHKHLLPMMLYLRKQLETS------------------------1125 PFGLRFGKR-------

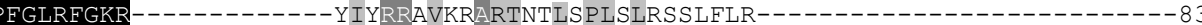

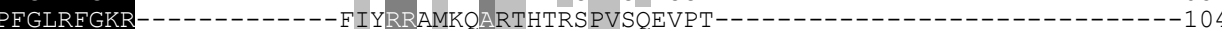

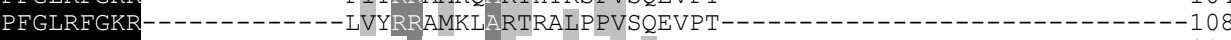

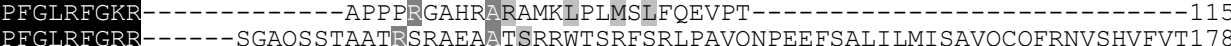




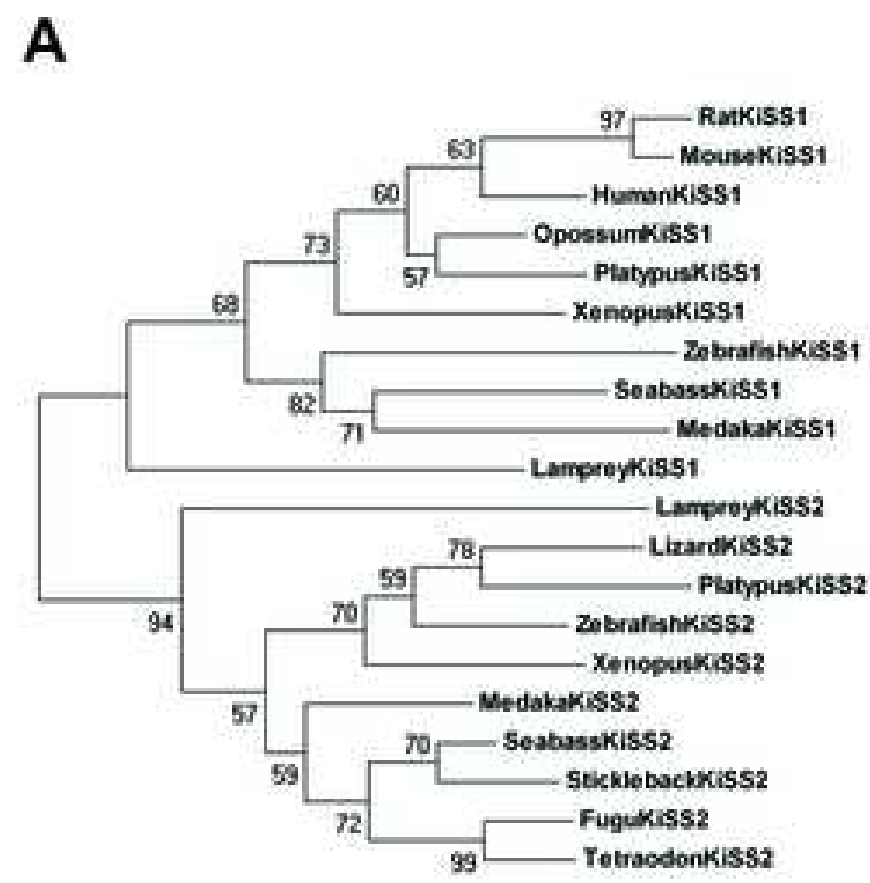

$\stackrel{51}{01}$

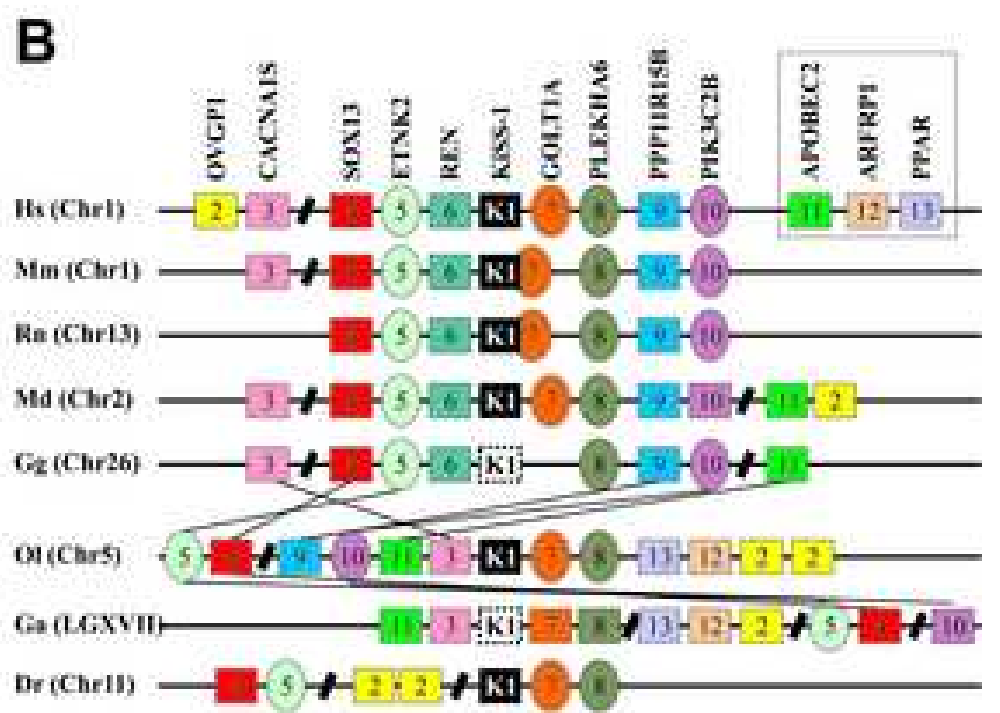

C

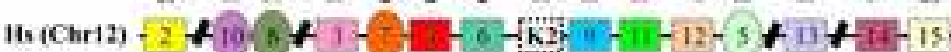

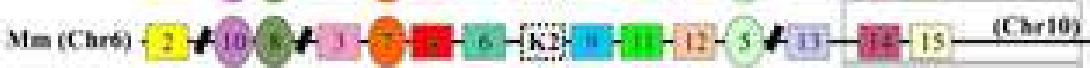

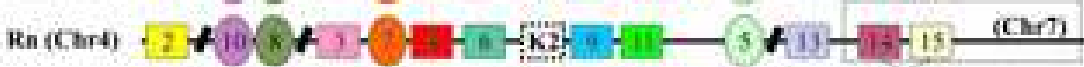

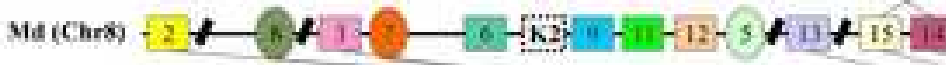

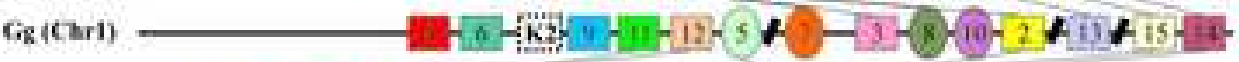

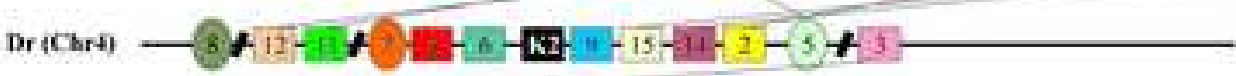

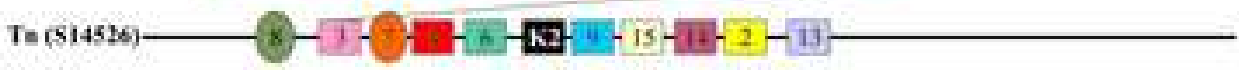

$\operatorname{Fr}(\$ 171)$

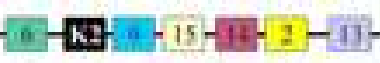

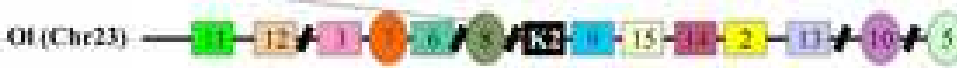

Gia (\$221)

K. $-15-2$ 


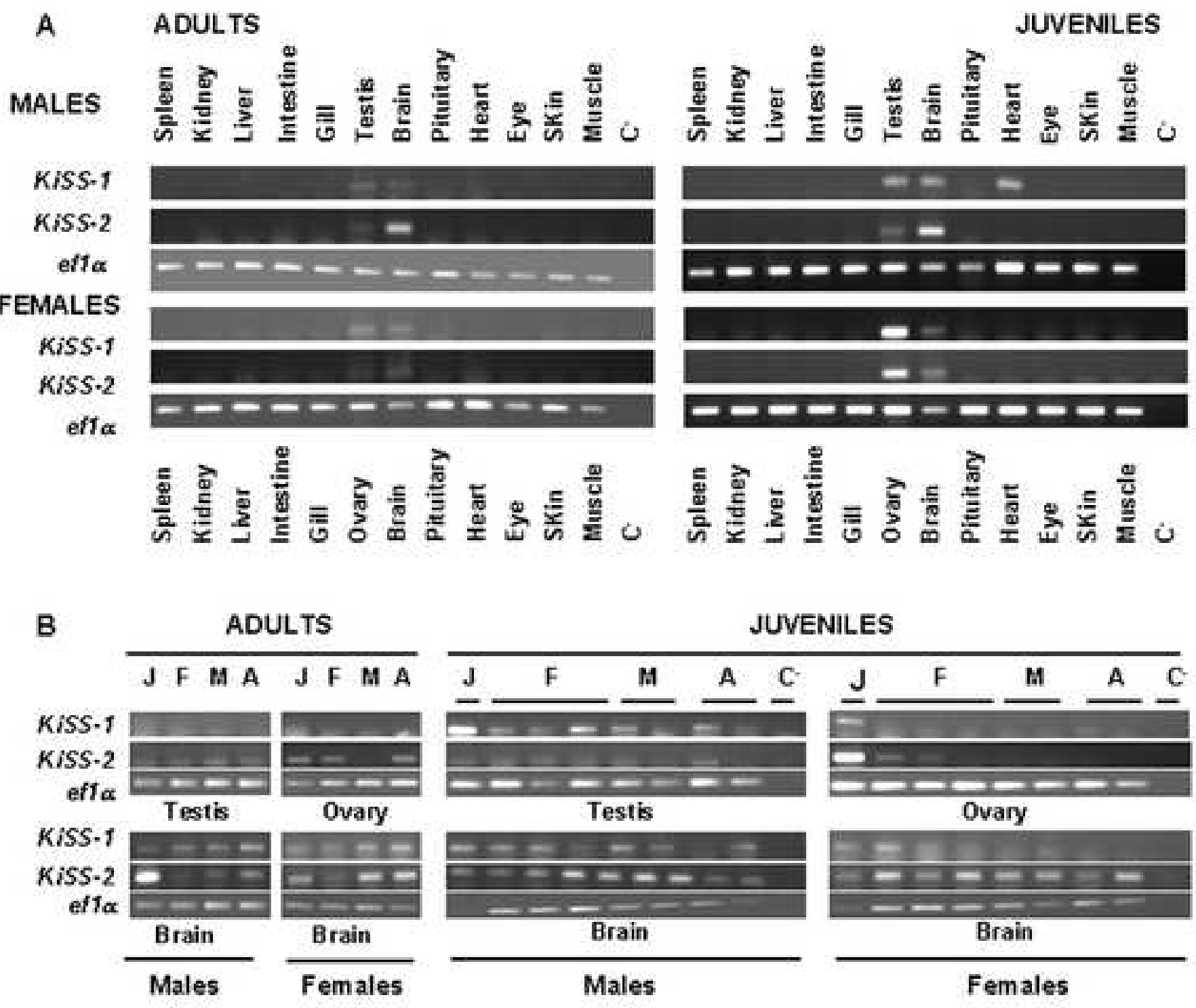


MEDAKA

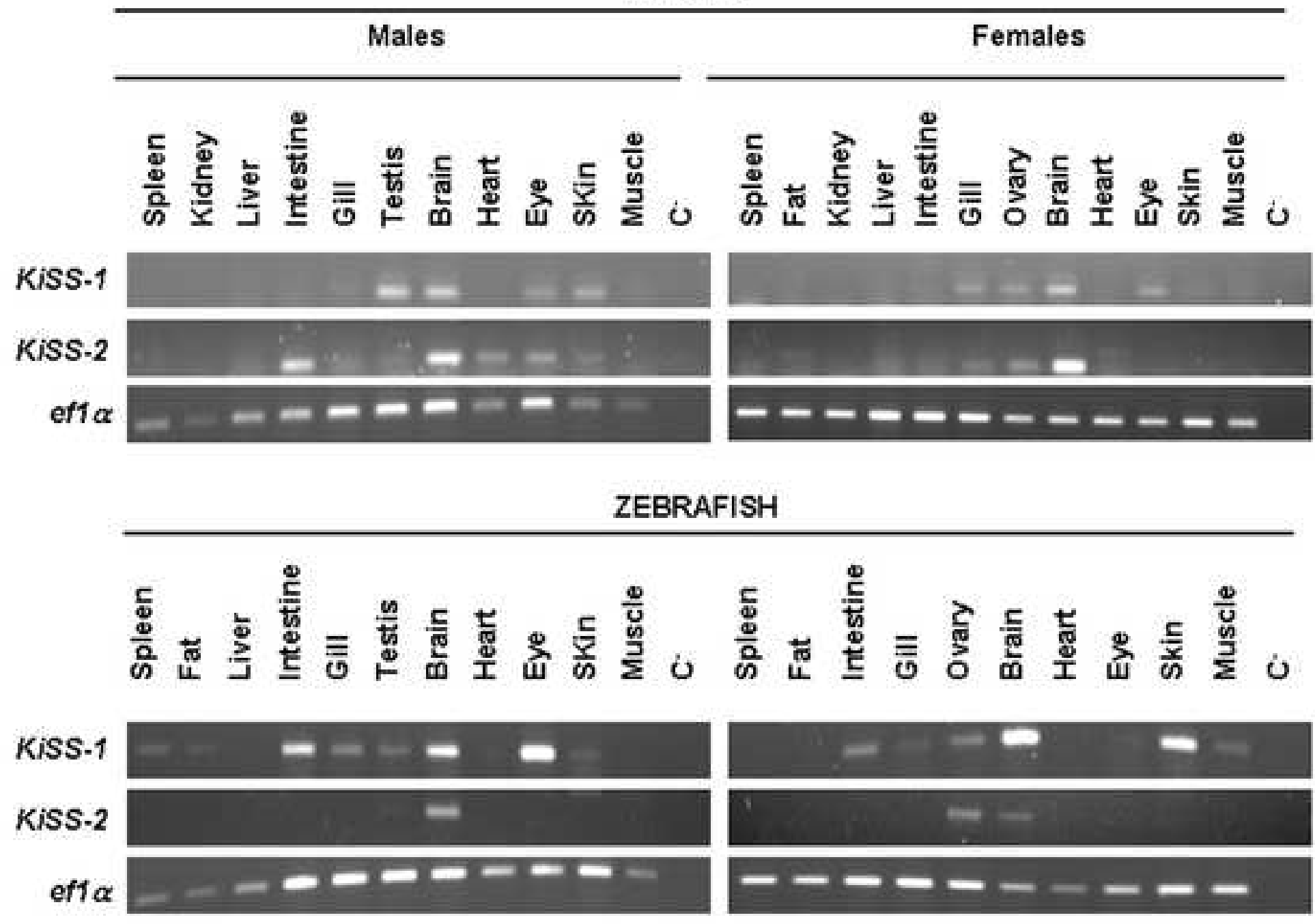



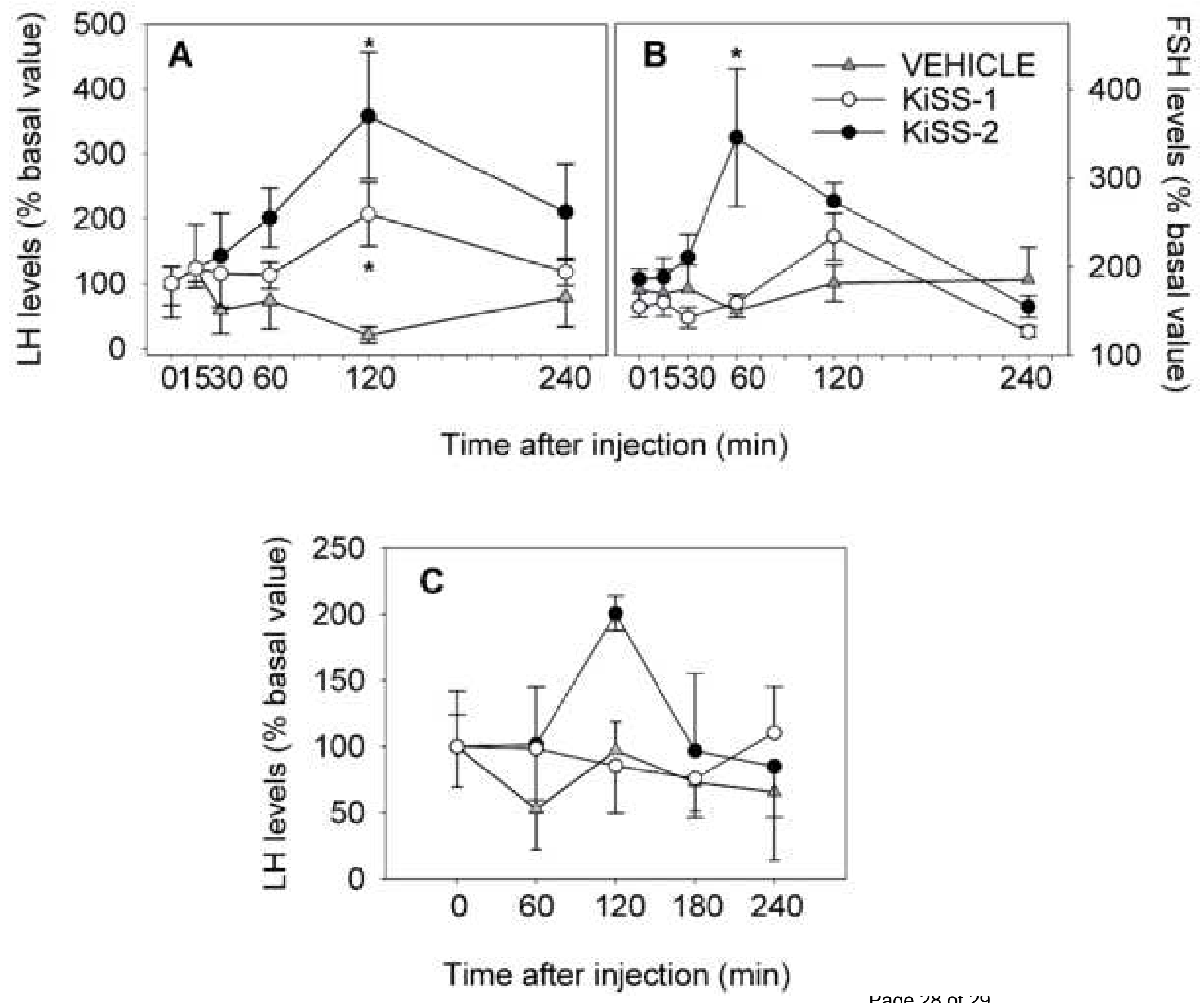


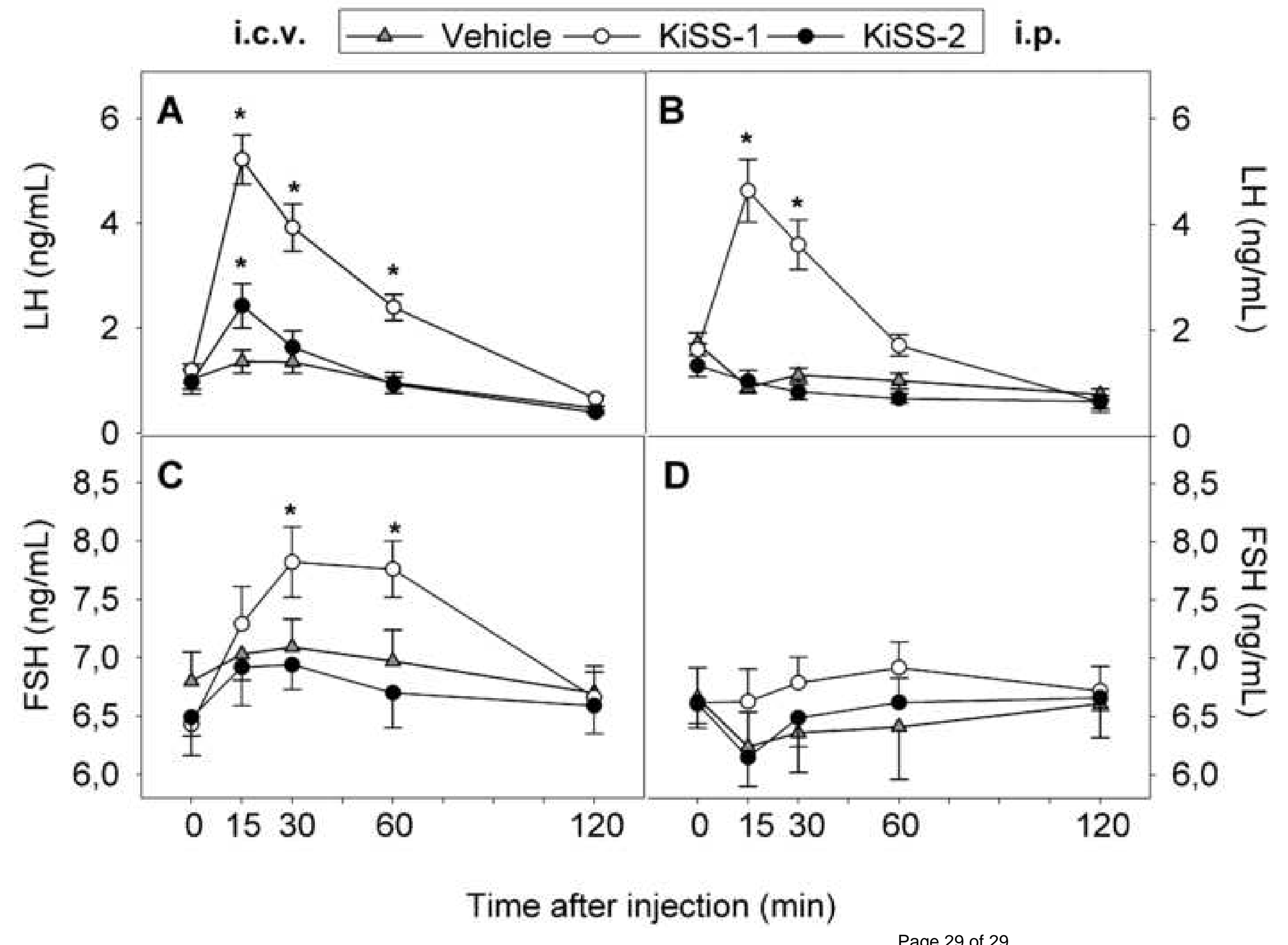

